NBSIR 83-2662

\title{
All101 4527?
}

Documentation and Assessment of the GSA/PBS Building Systems Program: Background and Research Plan
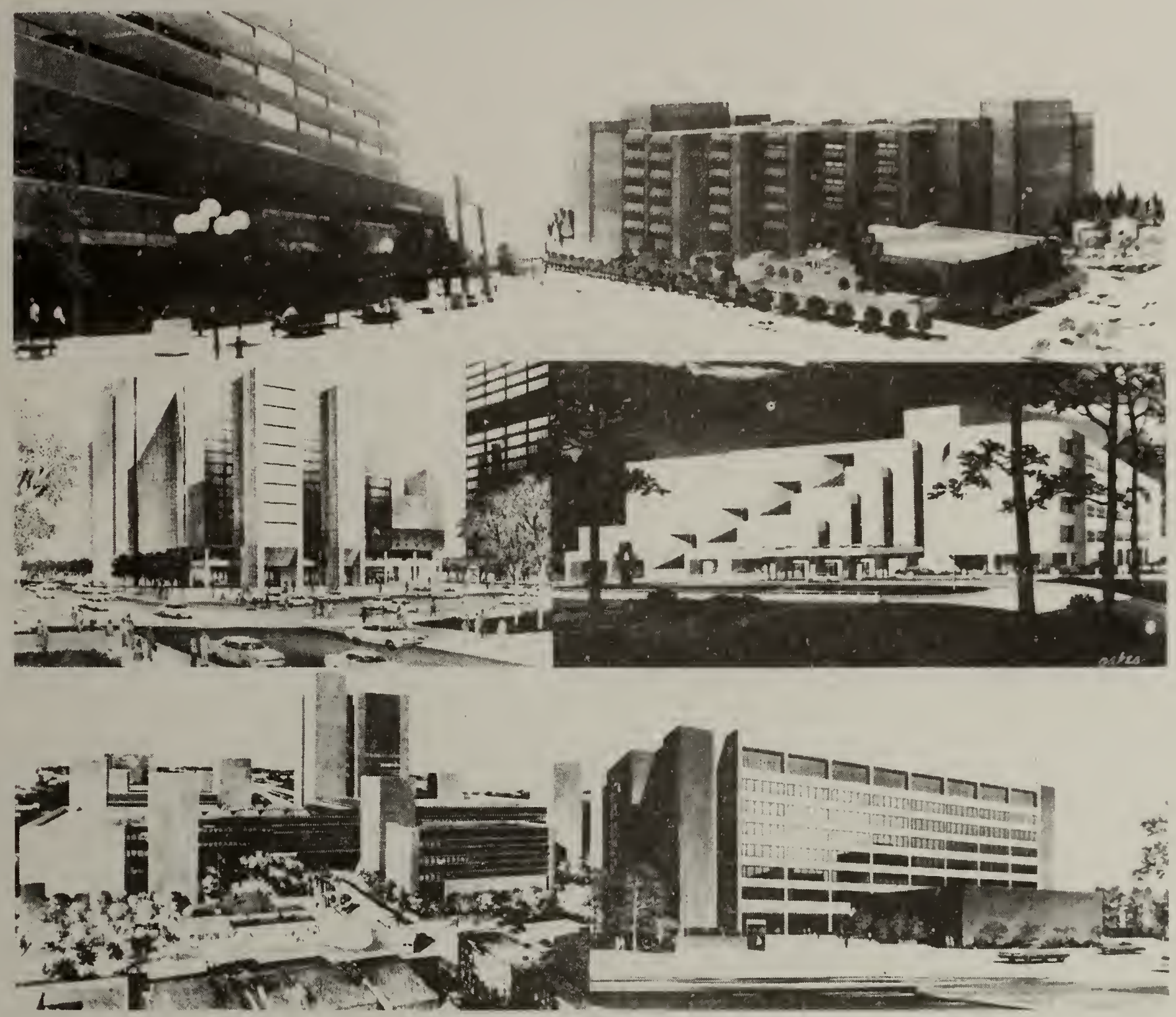

February 1983

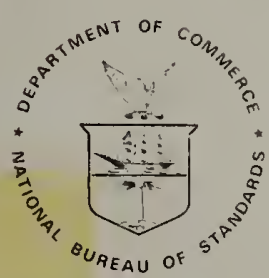

Center for Building Technology National Bureau of Standards Department of Commerce Washington, D.C. 20234

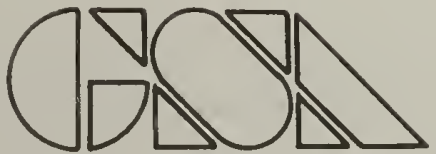

Office of Design and Construction Public Buildings Service General Services Administration Washington, D.C. 20405 

NBSIR 83-2662

DOCUMENTATION AND ASSESSMENT OF THE

GSA/PBS BUILDING SYSTEMS PROGRAM:

BACKGROUND AND RESEARCH PLAN

Francis T. Ventre

U.S. DEPARTMENT OF COMMERCE

National Bureau of Standards

National Engineering Laboratory

Center for Building Technology

Washington, DC 20234

February 1983

Sponsored by

Public Buildings Service

General Services Administration

Washington, DC 20405

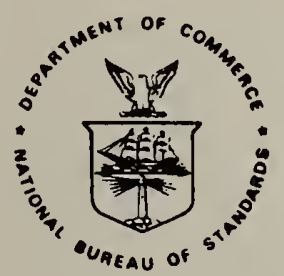

U.S. DEPARTMENT OF COMMERCE, Malcolm Baldrige, Secretary NATIONAL BUREAU OF STANDARDS, Ernest Ambler, Director 



\section{ABSTRACT}

This report documents the origins and conduct of the General Services Administration/Public Buildings Service (GSA/PBS) Bullding Systems Program (BSP) undertaken during the 1970 s and recommends a research plan for assessing the effectiveness of the BSP. The report proposes specific methods for assessing two outcomes of the BSP: the delivery of specified levels of performance for four attributes in the six buildings completed under the BSP and the wider effects of the BSP on the building community. 


\section{ACKNOWLEDGEMENTS}

Th1s report incorporates contributions from NBS staff members and consultants knowledgeable in the diverse technical areas included in the Performance Speciflcations for office Bulldings. These specialists lent their expertise to the indentification of assessment methods and field procedures for 1mplementing those methods. The speciallsts and areas of the report to which they contributed were:
K. R. Eberhardt
T. Hattenburg
R. W. Marans
(Untversity of Michigan)
F. F. Rudder
S. S1lberstein
F. I. Stahl

Statistical methods for sample surveys

Illumination measurements

Perceptual/behavioral measurements; general fleld methods

Acoustical measurements

Alr quality measurements

Exper1mental design

Several GSA/PBS staff members loaned documents and contributed advice (1ncluding comments on drafts of this report) as well as the1r personal recollections of the BSP. Those contributors were: J. Parker, E. Striner and C. Thomas.

James G. Gross, Chief of the CBT Office of Construction Programs, offered helpful comments at several stages. Final responsibility for the report as published, of course, rests with the author.

Cover Illustration:

The six BSP buildings, clockwise from upper right: SSA Western Program Center, Richmond CA; SSA Headquarters Expansion, Computer Building, Woodlawn, MD; SSA Mid-Atlantic Program Center, Philadelphia, PA; SSA Headquarters Expansion, Metro West Building, Baltimore, MD; SSA Great Lakes Program Center, Chicago, IL; Federal Building and Parking Facility, Norfolk, VA. 


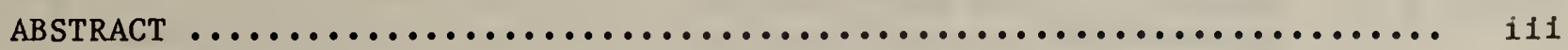

ACKNOWLEDGEMENTS $\ldots \ldots \ldots \ldots \ldots \ldots \ldots \ldots \ldots \ldots \ldots \ldots \ldots \ldots \ldots \ldots \ldots \ldots \ldots \ldots \ldots$ iv

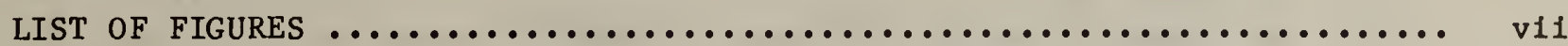

LIST OF TABLES $\ldots \ldots \ldots \ldots \ldots \ldots \ldots \ldots \ldots \ldots \ldots \ldots \ldots \ldots \ldots \ldots \ldots \ldots \ldots \ldots \ldots \ldots \ldots \ldots \ldots \ldots \ldots \ldots \ldots$

1. INTRODUCTION $\ldots \ldots \ldots \ldots \ldots \ldots \ldots \ldots \ldots \ldots \ldots \ldots \ldots \ldots \ldots \ldots \ldots \ldots \ldots \ldots \ldots \ldots \ldots \ldots . . \ldots$

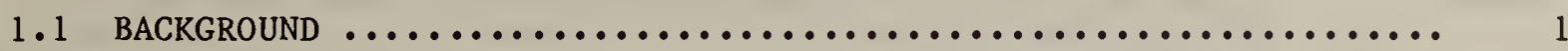

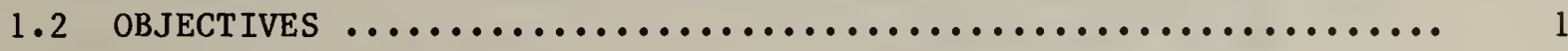

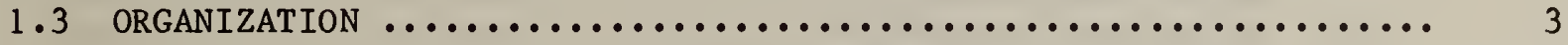

2. DOCUMENTATION: BACKGROUND FOR THE BUILDING SYSTEMS PROGRAM (BSP) ... 4

2.1 HOW NEW BUILDINGS CAME ON STREAM .................... 4

2.2 WHAT KINDS OF BUILDINGS CAME ON STREAM $\ldots \ldots \ldots \ldots \ldots \ldots \ldots \ldots \ldots \ldots . \ldots$

2.3 PBS EFFORTS AT REFORM OF THE CONSTRUCTION PROCESS AND PRODUCT $\ldots$

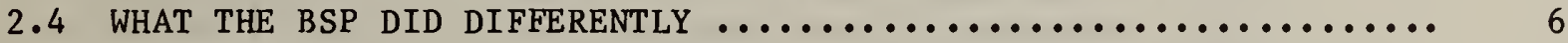

2.5 PRECEDENTS IN PUBLIC CONSTRUCTION $\ldots \ldots \ldots \ldots \ldots \ldots \ldots \ldots \ldots \ldots \ldots \ldots \ldots$

2.6 FROM SEQUENCE TO SYSTEM VIA THE TWO-STEP PROCUREMENT PROCESS ... 9

2.7 BSP'S DISTINCTIVE GOALS AND APPROACHES $\ldots \ldots \ldots \ldots \ldots \ldots \ldots \ldots \ldots \ldots \ldots \ldots$

2.8 THE STRUCTURE OF THE PERFORMANCE SPECIFICATIONS $\ldots \ldots \ldots \ldots \ldots \ldots .14$

3. DOCUMENTATION: EVOLUTION OF THE BUILDING SYSTEMS PROGRAM (BSP) ..... 19

3.1 CONSTANT AIMS, CHANGING METHODS $\ldots \ldots \ldots \ldots \ldots \ldots \ldots \ldots \ldots \ldots \ldots \ldots$

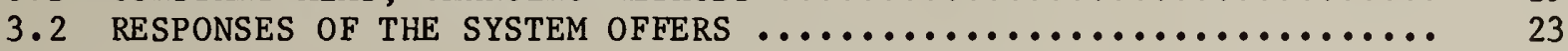

4. DOCUMENTATION: HOW GSA/PBS SPECIFIED BUILDING PERFORMANCE ........ 24

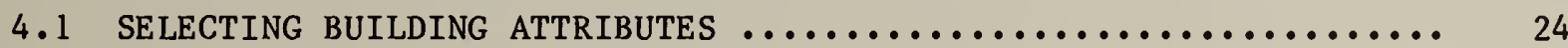

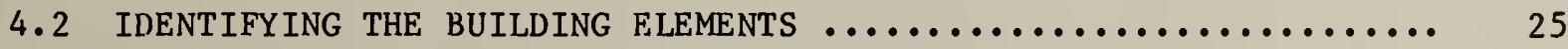

5. THE FIELD ASSESSMENT PROCESS $\ldots \ldots \ldots \ldots \ldots \ldots \ldots \ldots \ldots \ldots \ldots \ldots \ldots \ldots \ldots \ldots \ldots$

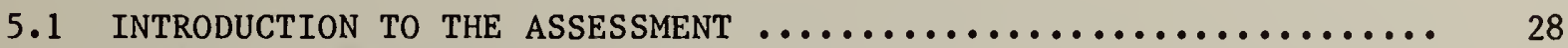

5.2 SELECTING ATTRIBUTES FOR FIELD ASSESSMENT $\ldots \ldots \ldots \ldots \ldots \ldots \ldots \ldots \ldots .28$

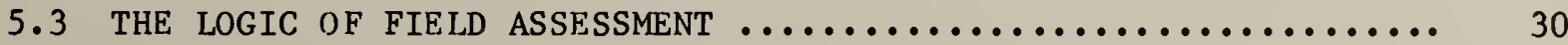

6. ASSESSING THE WIDER EFFECTS OF THE BSP .................... 34

6.1 CHARACTERIZING THE INNOVATIVE ELEMENTS OF THE BSP .......... 34

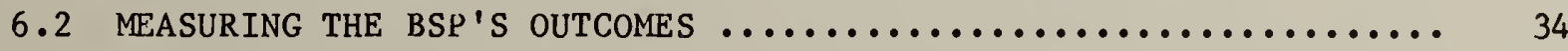

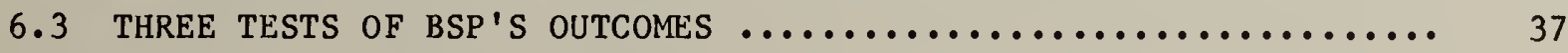

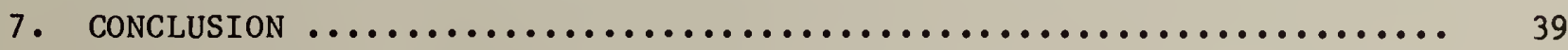


APPENDIX A. SUMMARY OF METRO WEST YILOT RUN $\ldots \ldots \ldots \ldots \ldots \ldots \ldots \ldots \ldots \ldots \ldots \ldots$ A-1

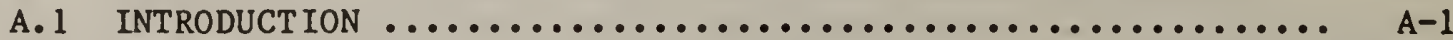

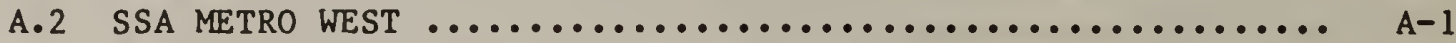

A.3 MEASUREMENTS OF THE PHYSICAL ENVIRONMENT $\ldots \ldots \ldots \ldots \ldots \ldots \ldots \ldots$ A-6

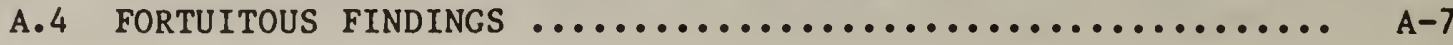

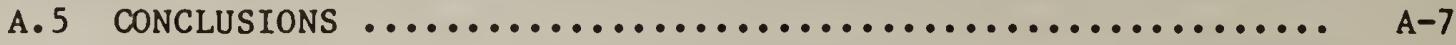

APPENDIX B. TECHNICAL COMMENT ON MEASUREMENT METHODS $\ldots \ldots \ldots \ldots \ldots \ldots \ldots$ B-1

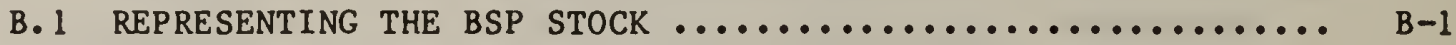

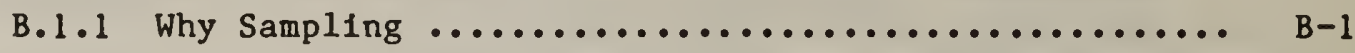

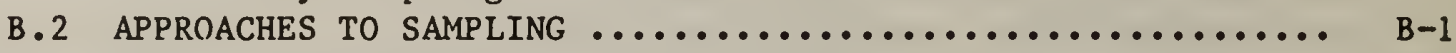

B.3 FACTORIAL EXPERIMENTAL DESIGN $\ldots \ldots \ldots \ldots \ldots \ldots \ldots \ldots \ldots \ldots \ldots \ldots . . . \cdots$

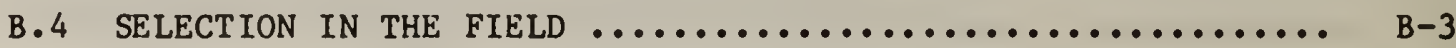

B.5 PHYSICAL MEASUREMENTS $\ldots \ldots \ldots \ldots \ldots \ldots \ldots \ldots \ldots \ldots \ldots \ldots \ldots \ldots \ldots \ldots \ldots$ B-5

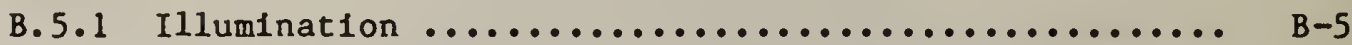

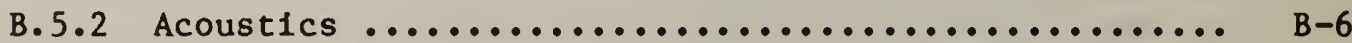

B.5.3 Conditioned Air (movement) ....................... B-6

B.5.4 Planning (flexibility of interfor space division) .. $B-7$

B.6 PERCEPTUAL/BEHAVIORAL MEASUREMENTS $\ldots \ldots \ldots \ldots \ldots \ldots \ldots \ldots \ldots$ B 


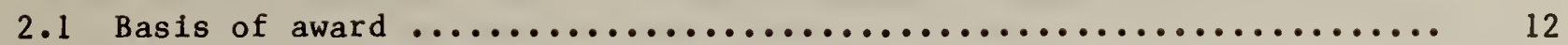

2.2 Matrix relating performance attributes to built elements ........ 16

2.3 Ranges in performance potential $\ldots \ldots \ldots \ldots \ldots \ldots \ldots \ldots \ldots \ldots \ldots \ldots \ldots . . \ldots \ldots$

3.1 Information flows and reporting relationships at the beginning

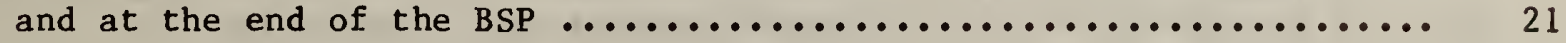

5.1 Logic of field assessment $\ldots \ldots \ldots \ldots \ldots \ldots \ldots \ldots \ldots \ldots \ldots \ldots \ldots \ldots \ldots \ldots$

A.1 Architectual rendering of Metro West (view from the east) ........ A-2

A.2 Location of Metro West .............................. A-3

A.3 Section through Metro West ............................ A-4

A. 4 Metro West column, core and entrance plan .................. A-5 
1.1 Completed Building Systems Program Projects ................. 2

2.1 Selected Precedents for Precoordinated Construction of Public

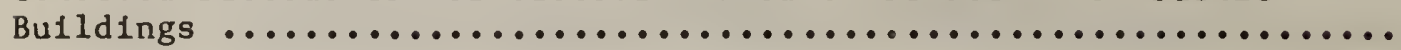

2.2 Successive Editions of the Peach Book, with Issue Dates and Abbreviated Designations

2.3 The "In System" and "Out of System" Elements of the Building

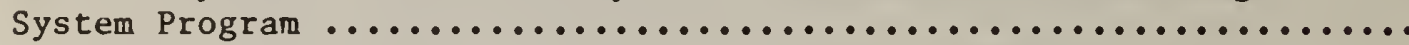

2.4 Relation of BSP's Two-Step Procurement Process to Stage in the Sequential Contracting Process .........................

3.1 Summary of Changes to the Introductory Sections of Each Edition of

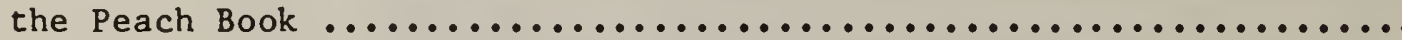

5.1 Significant Technical Changes Incorporated in Each Edition of the Peach Book and Rationales for the Changes .....................

5.2 Bullding Performance Attributes Selected for NBS Field Measurement

6.1 Outcomes of BSP Process and Product Innovations $\ldots \ldots \ldots \ldots \ldots \ldots \ldots$

B.1 Potentially Significant Subdivisions of BSP Environments ........ B-4

B.5.4.1 Rate of Change and Area of Change Factors for Planned Change of BSP Interiors 


\subsection{BACKGROUND}

In the early 1970s, the General Services Administration/Public Buildings Service (GSA/PBS) broadened its facilities procurement procedures to include such innovations as a "Two-step" procurement process; a wider use of "building systems" concepts; articulation and coordination of "in-system" and "out-ofsystem" elements; the development and use of performance specifications for building systems and subsystems; construction management for "phased" project execution; and bid evaluation based on life cycle costsl. These innovations -differing from "conventional" practice and later collectively named the PBS Building Systems Program (BSP) -- were introduced in three series of building projects: Series I, Social Security Administration (SSA) Program Centers in Richmond, CA; Chicago, IL; and Philadelphia, PA; Series II, SSA Administrative Headquarters Expansions in Baltimore and Woodlawn, ID; and Series III, a multitenanted Federal office building in Norfolk, VA. The buildings are briefly described in table 1.1 .

Although the PBS Building Systems Program evolved continually through its lifetime (roughly, the decade of the 1970s), the program remained focused on the cost effective delivery over a structure's life cycle of "building performance which responds directly to the actual needs of building users." And, while the project's primary reference was to the shelter needs of Federal agencies, the program, from the start, anticipated the potential adoption of any or all of the system's components by other government building agencies (including States and municipalities) and by the private sector, particularly the designers and builders of owner-occupied commercial offices. 2

\subsection{OBJECTIVES}

The GSA/PBS asked the National Bureau of Standards/Center for Building Technology (NBS/CBT) to document and assess the Building Systems Program (BSP) undertaken in the 1970s.

The objectives of the larger documentation and assessment project are:

- To assess how well the distinctive objectives of the PBS Building Systems Program were met in the six facilities built to the several editions of the Performance Specification for Office Buildings.

- To recommend, for implementation by PBS, opportunities for improved building technology and building procurement practices.

1 GSA/PBS, Performance Specification for Office Buildings (The "Peach Book"), 3rd Edition, November 1975, pp. A-4 - A-9.

2 GSA/PBS, Performance Specification ... A-1 - A-3. 


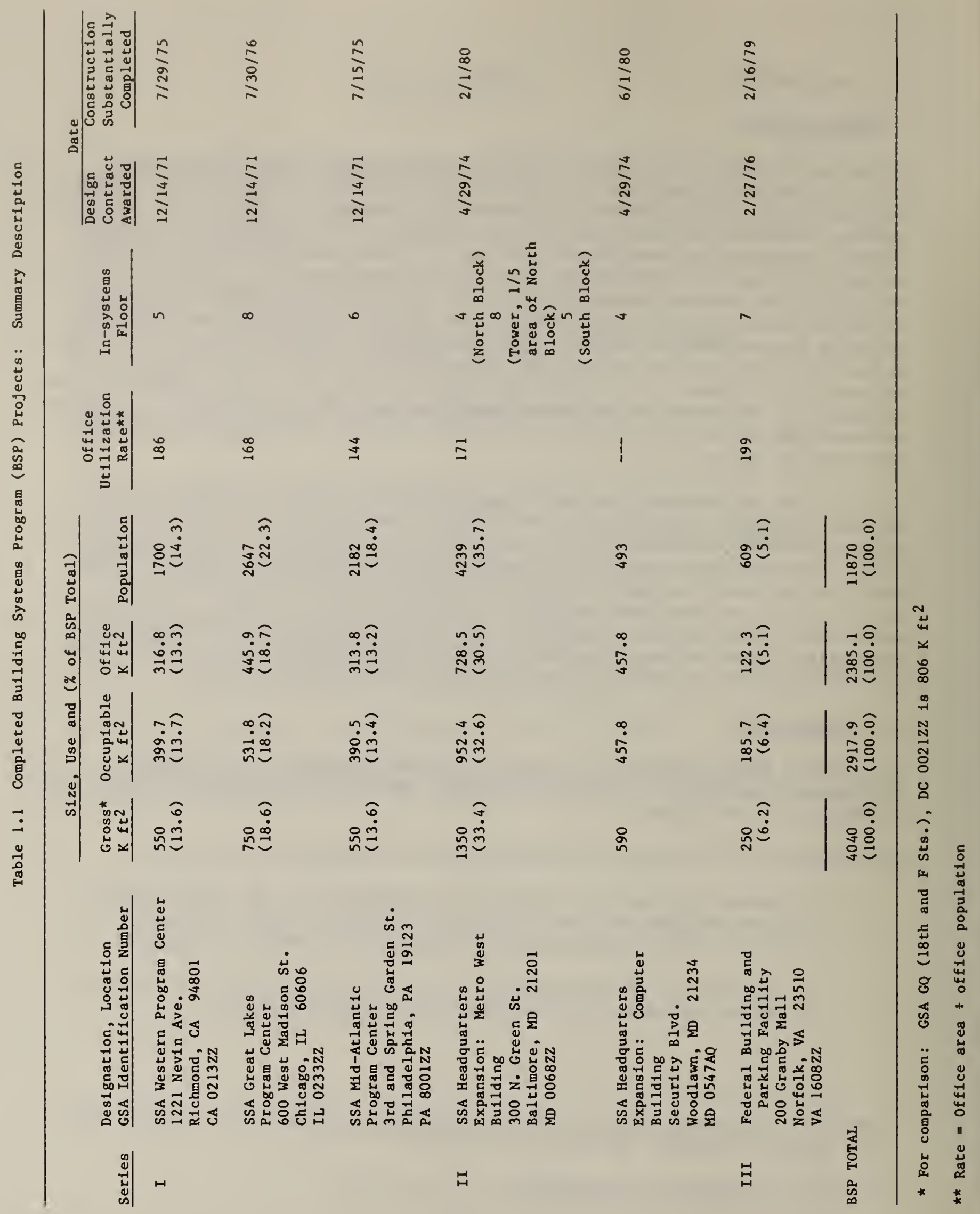


- To report on the advisability of implementing the Series III (prequalification) approach to building procurement.

o To identify significant building technology and procurement issues whose resolution will require further research.

The present report, however, has three more limited purposes. First, it focuses exclusively on the attributes of the BSP procurement process and resulting environments that were explicitly different from then-current "conventional" PBS practices. In other words, elements common to all processes (conventional and BSP) are categorically excluded from the present analysis which concentrates on the "In-system" building components. Second, this report, having identified the BSP's distinctive process and product objectives, then establishes methods for measuring the extent to which these objectives were achieved in the construction of the six buildings built during the BSP. Third, means for documenting the extent to which BSP process and product innovations benefited the building community at large are described. The project's findings will be presented in subsequent reports to GSA/PBS.

\subsection{ORGANIZATION}

This report is in two parts: a documentation section (Chapter 2-4) that is largely a historical narrative and an assessment section (Chapters 5-6) addressing issues of research method. The documentation section presents: (1) a schematic crosswalk between the "conventional" GSA/PBS method of procuring newly-constructed buildings prevailing at the time the BSP was initiated and the BSP's "Two-step" procurement process introduced in January, 1971. The crosswalk illustrates how bullding procurement differed under the BSP; and (2) a narrative and tabular representation of how the BSP objectives changed as the BSP progressed through the four stages of its evolutionary development. The documentation sections conclude with: (3) a discussion of GSA/PBS rationale for selecting seven building performance attributes for including the Performance Specification for Office Buildings (known familiarly as the "Peach Book").

The assessment section begins with: (4) NBS/CBT's criteria for selecting attributes for field assessment and a discussion of attributes chosen; (5) a schematic representation of NBS/CBT's field assessment process, incorporating both physical and behavioral measurement methods ${ }^{1}$; $(6)$ a description of factors influencing the approach taken to measure the extent of wider industry benefit traceable to the process and product innovations of the BSP; and (7) specific plans for measuring industry adoption of the "Peach Book" innovations. A brief conclusion section ends the report.

1 GSA/PBS subsequently postponed collecting the perceptual/behavioral responses of the buildings' occupants. 


\section{DOCUMENTATION: BACKGROUND FOR THE BUILDING SYSTEMS PROGRAM (BSP)}

\subsection{HOW NEW BUILDINGS CAME ON STREAM}

Virtually all GSA/PBS's procurement of newly-built federal office buildings in the late 1960s followed the sequential "design-bid-construct" system, then the prevalent one in the commercial and institutional sector of the Nation's building industryl. While the sequential system had the advantage of retaining very familiar and relatively clear contractual relations among the several parties at interest, it was not without critics - both inside and outside PBS. The sequential design-bid-construct system -- whether employed in the private or the public sector - was plagued in the late 1960s with cost increases that far exceeded the rises in the costs of goods and services in the economy as a whole. Rising costs of various factor inputs to construction (unit costs of materials, labor, and capital, for instance) contributed to this increase and more economical bullding design practices were pursued to control these costs. But another approach drew the attention of the construction community: this was to attack what some industry analysts felt was the excessively long duration of the construction process. And, because the construction industry makes heavy use of debt financing, the adage "Time is money" applies to construction with even stronger force. "How could buildings be completed faster?" was the question before the industry as a whole.

\subsection{WHAT KINDS OF BUILDINGS CAME ON STREAM}

While budget analysts and controllers were concerned about mounting costs of new construction, others were concerned about the suitability, fitness for purpose, and appearance of buildings in American cities and towns. The sleeklyfinished and often repetitive forms of modern architecture had, by the $1950 \mathrm{~s}$ and 1960s, grown visually stale to laymen and critic alike. Jane Jacobs 2 and Lewis Mumford ${ }^{3}$, among countless others, derided the appearance and lack of humanizing qualities in contemporary built form. Only slightly later, social scientists began to look for scientific explanations for why buildings that met technical criteria for safety and economy -- and even those winning awards for architectural excellence - evoked reactions of indifference and sometimes hostility from the users for whom the buildings were intended. 4 If the users were employees, then, some argued (but could not yet demonstrate conclusively), the lack of a supporting environment might even have negative consequences for the productivity of the enterprise sheltered in the unsatisfactory buildings.

1 The term construction is used in this report to mean construction of buildings only. That is, construction of highways and public works, such as sewer and water systems and transportation projects, is not included except as noted.

2 The Death and Life of Great American Cities (New York: Vintage, 1981).

3 From the Ground Up, (New York: Harcourt, Brace, 1956).

4 Summarized in Brent C. Brolin, The Failure of Modern Architecture (New York: Van Nostrand - Reinhold, 1976). 
These kinds of ideas about environments were "in the air" at the time the BSP was conceived and initiated; acknowledging this atmosphere might help to explain why PBS attempted, through the BSP and other methods, to reform existing, and devise new, building procurement methods.

\subsection{PBS EFFORTS AT REFORM OF THE CONSTRUCTION PROCESS AND PRODUCT}

Among the "other" reforms PBS considered and adopted in the early 1970s was the reconsideration of the entire building procurement process documented in Construction Contracting Systems ${ }^{1}$. Some suggested changes addressed the procedures of legislative authorization for, and funding of, building projects or with the mechanics of contract award, inspection, acceptance, and payment. These subjects are beyond the scope of the present study, however, and will not be further considered.

The design-and-construct segments of the cited report, on the other hand, indicated that the sequential process kept the several team members not only apart from one another during the program-design-bid-build-evaluate process but, even worse, required actions in advance by some participants that might preempt the design and management inputs of team members (including GSA's own staff) who joined the sequential process at a later point. Important cost-saving options in building operations and maintenance, for instance, might be precluded because previously made design decisions preempted them. The primary documentary link between occupants and designers was in the guide specifications that GSA conveyed to the project's designers. But GSA's own professionals reported to the GSA Adrainistrator that, despite a "crash effort" made in 1967 to improve the guide specifications, "they may still be used in ways that are restrictive and deny government buildings the latest developments in materials and construction techniques."

GSA building programming, according to the agency's internal study team, referred more to the "manner" in which space was to be used as distinguished from the "quality" of the space required. Moreover, the building program generally lacked detail, forcing the architect to undertake research that delayed commencement of design. "This results in slippage through remaining sequences." But, the internal GSA team reported, the

...most significant cause of schedule slippage is the performance of [design] reviews on a sequential basis with the architect stopping work pending the completion of each review. [One further effect of slippages is that designers] may find it impractical to assign the same personnel to the project throughout its life.

1 Construction Contracting Systems: A Report on the Systems Used by PBS and Other Organizations, GSA/PBS, March 1970. All quotations in Section 2.3 are from this document. 


\subsection{WHAT THE BSP DID DIFFERENTLY}

The BSP tried to overcome most of the aforementioned difficulties by introducing a process for doing three things: 1) for defining the "qualities" of proposed buildings in terms of the physical and psychological needs of the ultimate users and not the "manner" of the buildings' construction or use; 2) for constructing the users immediate surroundings not by a design-bid-construct sequence of discrete and compartmentalized autonomous contractors, but by a single, unified team whose services were delivered not serially but in a single package, an integrated "kit of parts": this kit was "The System" and its components were referred to as the "In-System" parts of the planned BSP buildings. The interior of typical office floors - estimated to account for 40 percent of an office building's cost -- would be assembled from this "systems" kit; and 3) for introducing life cycle costing as a basis of procurement, making the initial design-build team responsible for the performance of the user's environment for a specified period of time.

The initial private and public sector concern for cost containment was, in theory, to be met on four fronts: 1) by treating design-bid-construct simultaneously rather than serially, time savings would accrue (after the initial round of prototype building, of course); 2) life cycle costs would be known in advance and, thereby, more amenable to control; 3) since federal office workers the Nation over, would (or should) be working in environments of the same "quality", the unified interior package (kit of parts) could be reproduced anytime an addition to PBS's stock of federal office buildings was contemplated, thus, offering the possibility of scale economies in building procurement; and 4) since workers in commercial offices would need approximately the same "quality" of work environment, the suppliers of the federal office interior systems could increase even further the return on their initial investment in the research, development, design, and fabrication of the PBS office system through sales of these interior systems to the private sector.

\subsection{PRECEDENTS IN PUBLIC CONSTRUCTION}

Ample American and foreign precedent existed at the time the GSA/PBS undertook the BSP. Moreover, these precedents were made by public agencies who were dealing with technical problems not unlike those of GSA/PBS. One problem was the need to expedite the construction process during postwar reconstruction in England. That effort generated a "kit of parts" approach to a widely repeated building type -- schools -- by 1948. California and Canadian precedents indicated that sophisticated environmental control systems also for educational use, were attainable in new ways. All these new ventures, being public sector enterprises, operated in the open view of the conventional construction service firms in their respective locales and had attracted wide attention in the professional press. Table 2.1 indicates the range of precedent available to the BSP as far as the "product," the physical object, was concerned. But what about the "process"? Here, GSA adapted practices from the American private sector. 
Table 2.1 Selected Precedents for Precoordinated Construction of Public Buildings

\begin{tabular}{|c|c|c|c|c|}
\hline SYSTEM/ & DATE & LOCATION & $\begin{array}{c}\text { DISTINCTIVE } \\
\text { FEATURES }\end{array}$ & $\begin{array}{c}\text { SYSTEMS } \\
\text { INCORPORATED }\end{array}$ \\
\hline $\begin{array}{l}\text { CLASP } \\
\text { Consortium of } \\
\text { Local Authorities - } \\
\text { Special Programme }\end{array}$ & 1948 & $\begin{array}{l}\text { Local school authorities } \\
\text { in Hertfordshire, England. } \\
\text { Drew world attention at } 1960 \\
\text { Milan Triennale design exhibit }\end{array}$ & $\begin{array}{l}\text { Structure and enclosure } \\
\text { system developed by private } \\
\text { fabricator (Brockhouse } \\
\text { Steel Structures, Ltd.) } \\
\text { to specifications prepared } \\
\text { by CLASP designees. Local } \\
\text { architects and contractors } \\
\text { design and construct } \\
\text { specific projects 1ncorpor- } \\
\text { ating elements packaged by } \\
\text { Brockhouse but now manufac- } \\
\text { tured by many suppliers. } \\
\text { W11l use In other indus- } \\
\text { trial countries. }\end{array}$ & $\begin{array}{l}\text { Structural frame and exterior } \\
\text { cladding and fenestrationa. } \\
\text { A "closed system" }\end{array}$ \\
\hline Nenk Method & 1960 & $\begin{array}{l}\text { Barracks rebuilt for } \\
\text { 36th Engineers Corps } \\
\text { Regiment, Invicta Park, } \\
\text { Maidstone, England }\end{array}$ & $\begin{array}{l}\text { Began with user interviews } \\
\text { to elicit design require- } \\
\text { ments what is now called } \\
\text { "predesign programming" }\end{array}$ & $\begin{array}{l}\text { Used an existing structural } \\
\text { system but obtained industry- } \\
\text { government cooperation on } \\
\text { design and development of } \\
\text { enclosure components.b }\end{array}$ \\
\hline $\begin{array}{l}\text { SCSD } \\
\text { School Construction } \\
\text { Systems Development }\end{array}$ & $\begin{array}{l}1961- \\
1963\end{array}$ & $\begin{array}{l}\text { Pooled procurement for } \\
22 \text { schools in } 13 \text { Cali- } \\
\text { fornia districts. } \\
\text { Prototype structure } \\
\text { erected at Menlo Park, } \\
\text { CA. Supported by } \\
\text { Educational Facilities } \\
\text { Laboratory (EFL) }\end{array}$ & $\begin{array}{l}\text { Educators and architects } \\
\text { devised an education speci- } \\
\text { fication, architects and } \\
\text { engineers converted to a } \\
\text { performance specification } \\
\text { for a two-step procurement } \\
\text { process, a forerunner of } \\
\text { that later adopted by } \\
\text { GSA/PBS. }\end{array}$ & $\begin{array}{l}\text { Structural; Cefling-Lighting; } \\
\text { HVAC; Interior Partitions. An } \\
\text { open system "kit of parts."C }\end{array}$ \\
\hline $\begin{array}{l}\text { SEF } \\
\text { Study for Educa- } \\
\text { tional Facilities }\end{array}$ & 1965 & $\begin{array}{l}\text { Metropolitan Toronto } \\
\text { (Ontario, Canada) } \\
\text { School Board. } \\
\text { Supported by EFL }\end{array}$ & $\begin{array}{l}\text { Two-step procurement to } \\
\text { specifications prepared } \\
\text { by education specialists } \\
\text { and building technologists } \\
\text { keyed to advanced concepts } \\
\text { in education. Schools in } \\
\text { Montreal, Buffalo, Florida } \\
\text { and Boston adopted varia- } \\
\text { tions of SEF approach. } \\
\text { Many used same subsystem } \\
\text { suppliers. }\end{array}$ & $\begin{array}{l}\text { Structure, HVAC, lighting- } \\
\text { ceiling, interior space } \\
\text { division, "vertical skin," } \\
\text { plumbing, electric-electronic, } \\
\text { "caseworks and furniture," } \\
\text { roofing, interior finish. } \\
\text { Open system of ten subsystems } \\
\text { (award procedure allowed four } \\
\text { acceptable proposals per sub- } \\
\text { system ylelding } 1,048,576 \\
\text { possible systems)d. }\end{array}$ \\
\hline
\end{tabular}


Table 2.1 (Continued)

\begin{tabular}{|c|c|c|c|c|}
\hline SYSTEM/ & DATE & LOCATION & $\begin{array}{c}\text { DISTINCTIVE } \\
\text { FEATURES }\end{array}$ & $\begin{array}{c}\text { SYSTEMS } \\
\text { INCORPORATED } \\
\end{array}$ \\
\hline $\begin{array}{l}\text { RAS } \\
\text { Recherche en } \\
\text { Amanagement } \\
\text { Scolaire }\end{array}$ & 1968 & $\begin{array}{l}\text { Montreal (Quebec, Canada) } \\
\text { Catholic School Commission. } \\
\text { Supported by EFL. }\end{array}$ & $\begin{array}{l}\text { Life cycle costing formula } \\
\text { based on predicted service } \\
\text { life of each component and } \\
\text { a realistic discount rate. }\end{array}$ & $\begin{array}{l}\text { "Closed" system of subsystem } \\
\text { manufacturers bidding as } \\
\text { teams. } h\end{array}$ \\
\hline $\begin{array}{l}\text { URBS } \\
\text { University } \\
\text { Residential } \\
\text { Building System }\end{array}$ & 1965 & $\begin{array}{l}\text { Various University of } \\
\text { California campuses }\end{array}$ & $\begin{array}{l}\text { Early use of construction } \\
\text { management by an institu- } \\
\text { tional cllent to fix large } \\
\text { fraction of cost at early } \\
\text { stage of building process. }\end{array}$ & $\begin{array}{l}\text { Principle innovations were not } \\
\text { in hardware systems.e }\end{array}$ \\
\hline $\begin{array}{l}\text { NYSDA } \\
\text { New York State } \\
\text { Dormitory } \\
\text { Authority }\end{array}$ & 1968 & $\begin{array}{l}\text { Various public and private } \\
\text { institutions in New York State }\end{array}$ & $\begin{array}{l}\text { Modified turning into } \\
\text { phased design/build process } \\
\text { undertaken by prequalified } \\
\text { teams of contractors, } \\
\text { architects and engineers. }\end{array}$ & $\begin{array}{l}\text { Principle innovation was in } \\
\text { prequalification of teams, not } \\
\text { hardware systems of }\end{array}$ \\
\hline $\begin{array}{l}\text { SuSA } \\
\text { State Iniversity } \\
\text { System of Alaska }\end{array}$ & 1970 & $\begin{array}{l}\text { Nine projects on Seven sites } \\
\text { in Alaska }\end{array}$ & $\begin{array}{l}\text { Linked phase design/build } \\
\text { whth subsystems procurement } \\
\text { to achieve completion in } 20 \\
\text { months. }\end{array}$ & $\begin{array}{l}\text { Largely drawn from subsystems } \\
\text { initially developed to meet } \\
\text { SCSD performance criteria.1 }\end{array}$ \\
\hline
\end{tabular}

a Barry James Sullivan, Industrialization in the Building Industry, (New York. Van Nostrand Reinhold, 1980), 90-91.

b Institute for Applied Technology, National Bureau of Standards, Building Systems Innovation, a report prepared for the Commissioner of the Public Bulldings Service, General Services Administration, December 1965.

c Michael Glover (editor) Alternative Processes; Bullding Procurement, Design and Construction, IF Occasional Paper No. 2, Indusirialization Forum at the Un1versity of Illinois (March 1976), pp. 57-67.

d Sullivan, Industrialization 1n the Buflding Industry, pp. 91-124.

e Ezra Ehrenkrantz Critique in Leo A. Daly Case History, p. 251.

f Doug Hasbrouck and Phil Bobrow, in Glover, IF Occasional Paper No. 1, pp. 37-41.

g David B. Hattis, Letter, AIA Journal, December 1973, p. 55.

h Glover, IF Occasional Paper No. 2, p. 64 .

1 Ehrenkrantz, p. 252. 


\subsection{FROM SEQUENCE TO SYSTEM VIA THE TWO-STEP PROCUREMENT PROCESS}

In place of a seven-element sequence of conventional procurement for new vifice buildings, PBS offered a "Two-Step" process for the development of a building interior "system" that could be inserted into an otherwise "out of system" building that had been built conventionally. The seven elements of conventional building arel:

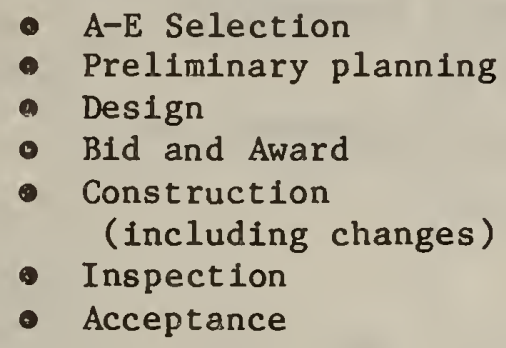

PBS intended to displace the seven-element sequence by soliciting from any person or entity qualified to do business with the government technical proposals for "furnishing and installation of building components" for certain federal office buildings, the buildings themselves to be individually designed by architects "who will employ in their final design the components herein solicited." The components' performance was specified in the Performance Specification for office Buildings ${ }^{2}$ (later known familiarly as "The Peach Book") which evolved, subsequently, through three editions (1isted in table 2.2) and numerous amendments from which the previous and following quotations are condensed.

The Two-Step procurement is comprised of:

STEP ONE -- TECHNICAL PROPOSAL - to be evaluated against the General Requirements and System Performance Specification sections of the Peach Book. Step One evaluation proceeded with no "consideration of price or pricing data." The elements of the proposed building to be included in the systems procurement and the separately contracted-for "Out of System" elements with which they were to interact are listed in Table 2.3.

STEP TWO -- BID - offerors of proposals deemed "acceptable" in Step One are invited to bid the installed price of the proposal system. The basis of award includes the considerations of maintenance and operation costs over a specified service life and is illustrated in figure 2.1 .

1 Adopted from Construction Contracting Systems.

2 See footnote 1, page 1. 
Table 2.2 Successive Editions of the Peach Book, with Issue Dates and Abbreviated Designations

\begin{tabular}{|c|c|c|c|}
\hline Formal Title & Issued & $\begin{array}{c}\text { Abbreviated } \\
\text { Designation }\end{array}$ & $\begin{array}{c}\text { Location of } \\
\text { Application }\end{array}$ \\
\hline $\begin{array}{c}\text { Performance specification } \\
\text { for office buildings }\end{array}$ & January 1971 & PB:I & \\
$\begin{array}{c}\text { Performance specification } \\
\text { for office buildings } \\
\text { (revised) }\end{array}$ & September 1971 & PB:1 & $\begin{array}{l}\text { Series I: } \\
\text { Philadelphia, PA } \\
\text { Chicago, IL } \\
\text { Richmond, CA }\end{array}$ \\
$\begin{array}{c}\text { Performance specification } \\
\text { for office buildings } \\
\text { (Second Edition) }\end{array}$ & June 1973 & PB:2 & $\begin{array}{l}\text { Series II } \\
\text { Baltimore,MD } \\
\text { Woodlawn, MD }\end{array}$ \\
$\begin{array}{c}\text { The PBS Building Systems } \\
\text { program and performance } \\
\text { specification for } \\
\text { office bulldings } \\
\text { (Third Edition) }\end{array}$ & November 1975 & PB:3 & $\begin{array}{l}\text { Series III } \\
\text { Norfolk,VA }\end{array}$ \\
\hline
\end{tabular}


Table 2.3 The "In-System" and "Out-of-System" Elements of the Building Systems Program

\begin{tabular}{|c|c|c|}
\hline \multirow[b]{2}{*}{ SUBSYSTEM } & \multicolumn{2}{|c|}{ BUILDING ELEMENTS } \\
\hline & $\begin{array}{l}\text { INCLUDED IN TWO-STEP } \\
\text { PROCUREMENT AND CONSIDERED } \\
\text { "IN-SYSTEM" }\end{array}$ & $\begin{array}{l}\text { TREATED UNDER CONVENTIONAL } \\
\text { CONTRACTOR PROCEDURES AND } \\
\text { CONSIDERED "OUT-OF-SYSTEM" }\end{array}$ \\
\hline Structure & $\begin{array}{l}\text { Structural frame and deck } \\
\text { Fireproofing }\end{array}$ & $\begin{array}{l}\text { Foundations } \\
\text { Stairs in cores }\end{array}$ \\
\hline HVAC & $\begin{array}{l}\text { Air handling } \\
\text { Filtration } \\
\text { Heat exchange } \\
\text { Distribution } \\
\text { Control elements }\end{array}$ & Generating plant (sic) \\
\hline $\begin{array}{l}\text { Electrical } \\
\text { distribution }\end{array}$ & $\begin{array}{l}\text { Office power raceway } \\
\text { Telephone raceway } \\
\text { Signal raceway } \\
\text { Floor outlets } \\
\text { Luminaire wiring (sic) }\end{array}$ & $\begin{array}{l}\text { Switchgear } \\
\text { Office power wiring } \\
\text { Telephone wiring }\end{array}$ \\
\hline Luminaires & $\begin{array}{l}\text { Lamps, ballasts to provide } \\
\text { uniform, task-oriented, } \\
\text { and background lighting }\end{array}$ & $\begin{array}{l}\text { Luminaires in out-of-system } \\
\text { spaces (e.g., corridors, } \\
\text { toilets, lobbies) }\end{array}$ \\
\hline Finished floor & $\begin{array}{l}\text { Resilient flooring } \\
\text { Carpet }\end{array}$ & $\begin{array}{l}\text { Flooring in out-of-system } \\
\text { spaces (e.g., corridors, } \\
\text { toilets, lobbies) }\end{array}$ \\
\hline Finished ceiling & Ceiling in offices & $\begin{array}{l}\text { Celling in out-of-system } \\
\text { spaces (e.g., corridors, } \\
\text { tollets, lobbies) }\end{array}$ \\
\hline Space dividers & $\begin{array}{l}\text { Partitions } \\
\text { Doors and hardware } \\
\text { Free-standing screens } \\
\text { Column enclosures }\end{array}$ & $\begin{array}{l}\text { Fixed walls (e.g., at } \\
\text { utility cores, building } \\
\text { envelope) }\end{array}$ \\
\hline
\end{tabular}

* Adapted from an undated GSA brochure office Building by System used to elicit wider building community interest in the BSP. 


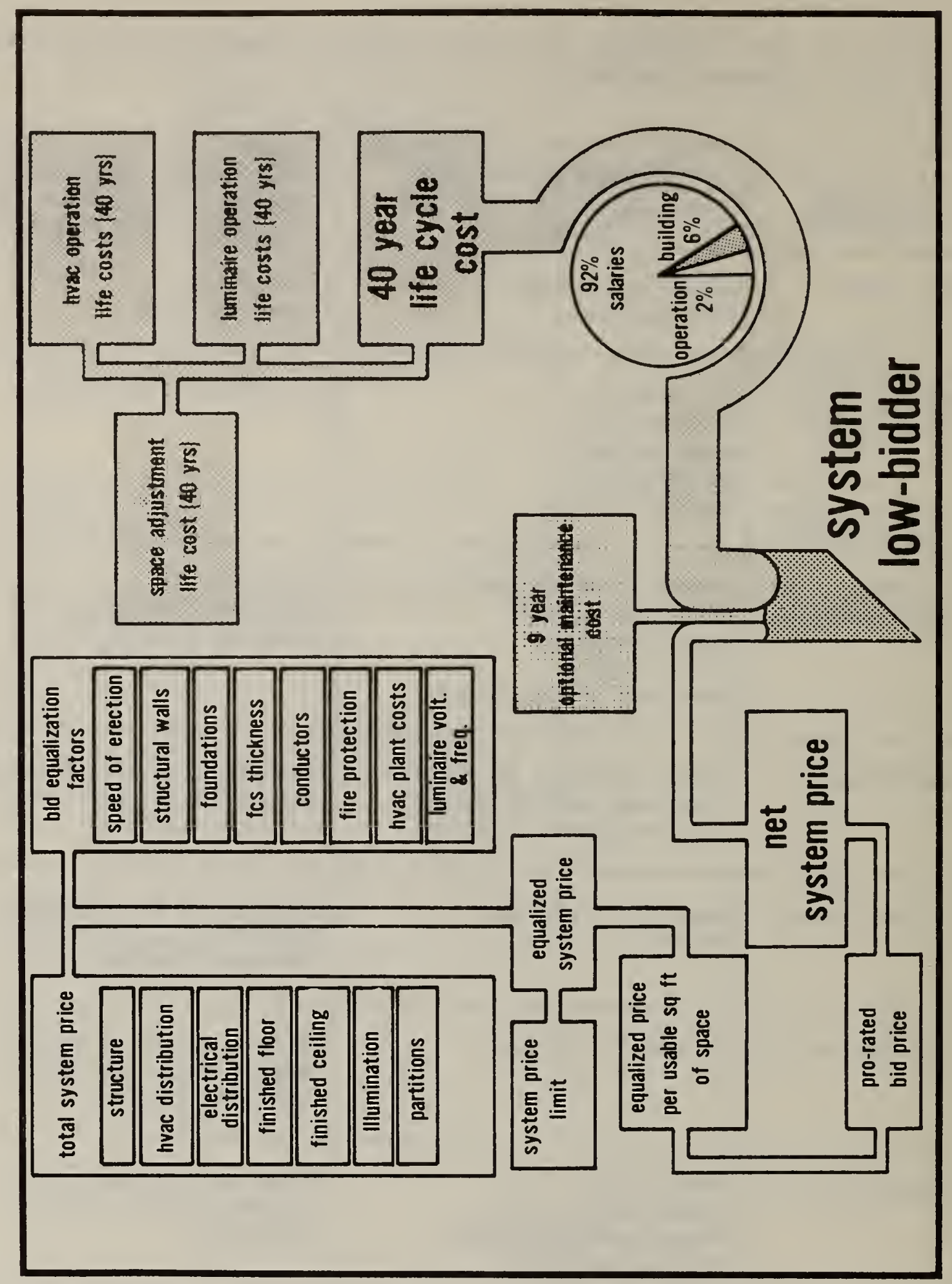

Figure 2.1 Basis of award. (Adapted from the Leo A. Daly (unpublished) report to PBS, The System Approach for Building Acquisition: A Case History of the GSA/SSA Program Centers System Building Project: 1971-1975, January 1976, p. 87. 
After the selection of the successful system, the previously-designated architects of the conventionally-constructed building were instructed to prepare their final designs completing the Out-of-System design and incorporating the successful system for the typical interiors of the office floors of the total structure.

The Two-Step System procurement process shared many objectives of the conventional PBS sequential procurement process -- cost effectiveness and architectural excellence, to mention just two. But some of the BSP goals were distinctive and had no counterpart in conventional procurement. These are listed later, as are a number of features that distinguished the BSP approach from the conventional, sequential process. But more important than the specific listing of goals and approaches was something harder to define but which nevertheless provided the driving energy of the BSP: this was a thoroughgoing committment to user needs-oriented technological innovation as the primary means for providing new federal offices. Whereas the previous building procurement procedures and documentation seemed to give primary emphasis to government as fiduciary of the public's funds under a restrictive, "zerodefects" approach to fiscal management, the BSP documents envisioned a bold new technological future for the commercial office building sector of the construction industry, with government leading the way into that future. To be sure, fiduciary responsibilities were not ignored, and all BSP procurements scrupulously followed Federal regulations, but the dominant mood of the entire procurement enterprise was one of technologically advanced methods for providing more satisfying and productive environments for federal office workers.

This mood was manifested in many ways: in the large number of meetings convened to acquaint members of the building community with the new approach 1 and in audiovisual presentations and brochures prepared for the same purpose. Analyzing the several editions of the Peach Book reveals that this eager sense of mission even found its way into the early editions of the procurement documents.

\subsection{BPS's DISTINCTIVE GOALS AND APPROACHES}

The differences between the BSP and the conventional approach are highlighted in table 2.4. The sequential steps of the conventional process are arranged across the top of the chart; the five elements of the BSP procurement down the left stub. For some of the intercepts in the resulting matrix, the conventional steps would be carried out as before. This occurs in Row 2 where the out-of-system elements of the new bullding -- siting, foundations, exterior envelope, special purpose spaces (including lobbies and auditoriums) and primary energy conversion equipment -were still handled under conventional sequencing of separate contracts with different contractors. The offerors of the "In-System" office interiors have no role here and the project architect is

1 For example, "More than 100 industry representatives attended GSA's recent systems offerors conference...", Building Design and Construction, November 1974. 
responsible for design decisions at the interface between the in-system and out-of-system components.

In Row 1, the system offerors complete the preliminary planning and design functions in order to qualify their systems for later competition. Recall that the Peach Book required no cost data at Step One of the new Two-Step procurement process.

Row 3 appears to coincide with the award phase of the sequential system. The basis for award, however, runs far beyond the lowest responsible bid based on first cost. Rather, the lump-sum bid required at Step Two of the Two-Step process was to reflect costs of maintenance and operation over a range of service lives specifled for different bullding components. Thus, Step Two was to bring life-cycle costs to the heart of the BSP. The several sets of factors comprising the basis of award is illustrated in figure 2.2, which, incidentally, is an accurate representation of the total BSP as operated in the earlier years. Row 4 indicates other ways that BSP differs from conventional sequencing of construction. In conventional work, most inspection and acceptance steps occur after the structure is completed and is nearing occupancy. But these steps, certifying that the system components (installed and tested in a prototype) comply with the performance specifications, were taken before the out-ofsystem working drawings for the entire project (entrained in. the sequence of conventional procurement) were even completed. Primary responsibility for Row 5 reverts to the construction manager for the total project who, in this phase, breaks the out-of-system work into bid packages, awards contracts and coordinates construction of in- and-out-of-system elements. The system team did not install the system elements -- the out-ofsystem contractor did that -- but the system contractor was to complete field tests as soon as the installation was complete.

It is clear from the foregoing that traditional relations in the construction process were sharply modified and redefined. GSA enhanced the construction management function and introduced an Executive/Architect-Engineer (1ater called Systems Consultant) role to establish a new network of information-flow since the traditional contractual relations of sequential construction no longer applied.

\subsection{THE STRUCTURE OF THE PERFORMANCE SPECIFICATIONS}

GSA/PBS conveyed to prospective supplies the desired qualities of the Federal office environment by means of the Peach Book specification. Although massive In size, the Peach Book's technical core, the "System Performance Specification", is organized with great clarity. The BSP's performance approach is embedded in the 49 cells of the seven by seven matrix 1llustrated in figure 2.2 . Each intercept of the matrix refers to more detalled information, recorded in the System Performance Specification section of each edition of the Peach Book, on how the built elements (the "hardware" of figure 2.1 and the "subsystems" of table 2.3) provide and control the desired performance attributes of the federal office environment. The seven-by-seven matrix imposed a rational consistency to the organization of each of the Peach Books, but the symmetry of the square matrix should not be misinterpreted to represent a consistent quality and 


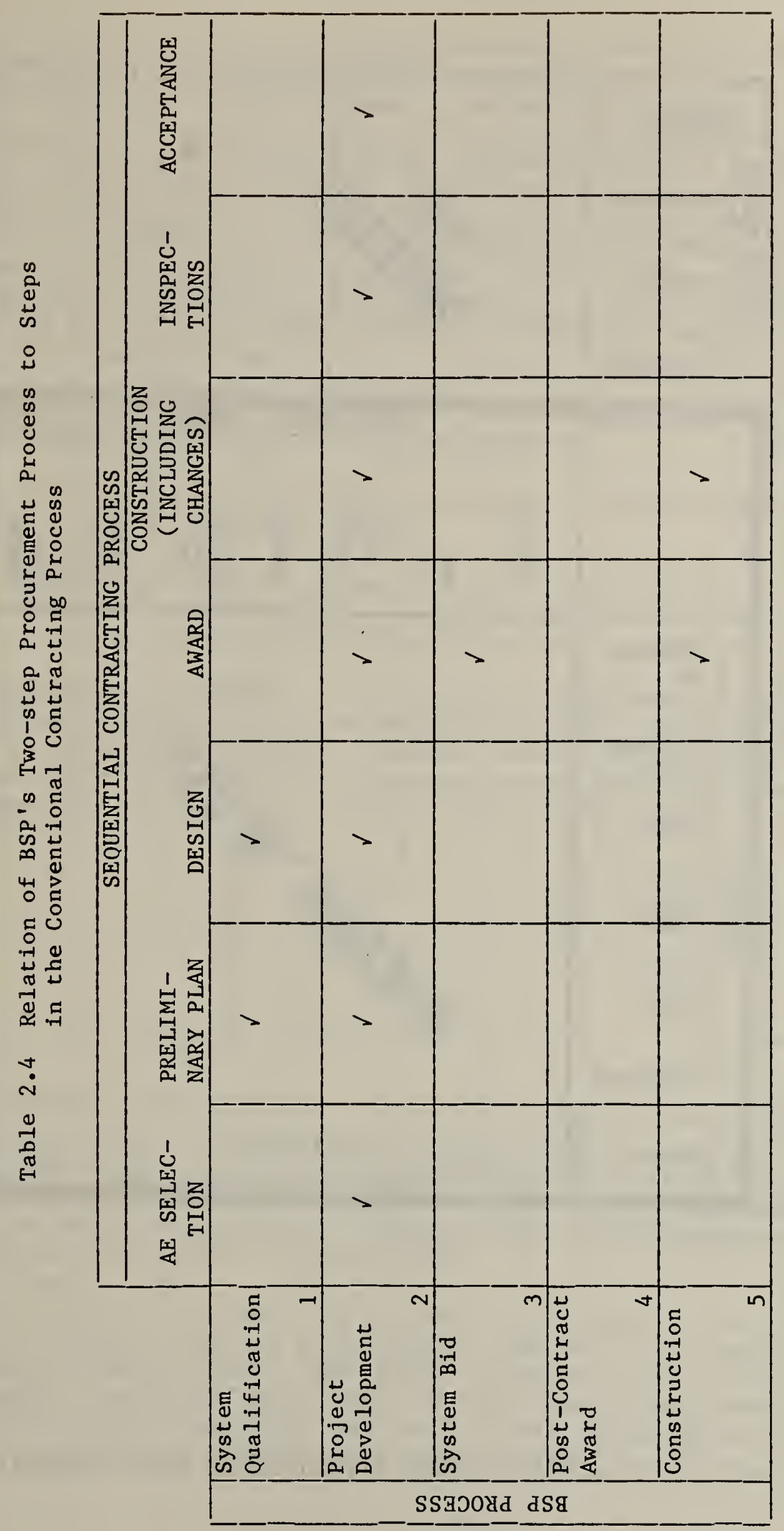




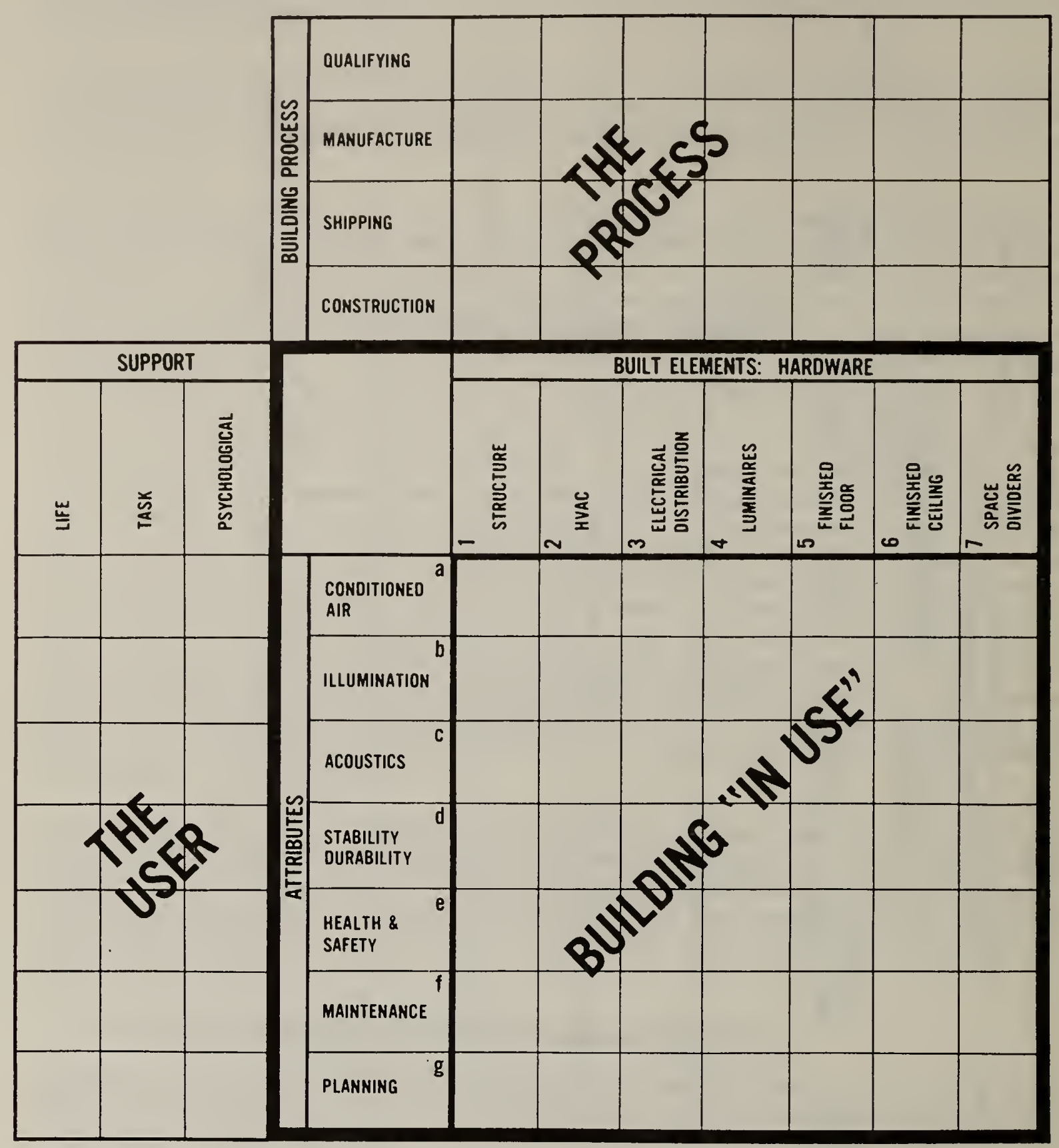

Figure 2.2 Matrix relating performance attributes to built elements 
importance of the information among the cells. While all the information organized by the performance matrix was necessary to achieve the BSP objectives, the significance of that information varied widely enough from cell-to-cell to suggest not a consistently flat, two-dimensional gridded plane of uniformly definitive information but, rather, a three-dimensional relief map of prisms, each of whose volumes represent varying degrees of rellable knowledge of building performance. Indeed, writing a correct performance statement requires much more systematic and thorough knowledge than writing a prescriptive specification. The variability of reliable performance information available during the writing of the Peach Book is illustrated in figure 2.3 and discussed in the detailed plans for assessment of the six buildings completed during the BSP (found in Chapters 5 and 6).

The information at each intercept of the performance matrix was contained in three categories:

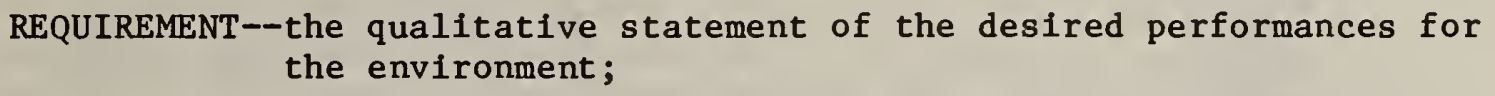

CRITERIA--a quantification of such desired performance; and

TEST--evaluative techniques assuring (sic) conformance with the criterial.

Isolating these elements of a performance specification is essential for a valid design evaluation, to be taken up in later chapters. The careful assessment of the completed building against initial design criteria becomes, when shared widely, a part of the collective memory of the building community and, consequently, a basis for improved design in the future ${ }^{2}$.

1 PB:1, P. B6. The terminology of the performance approach has grown in precision since the pioneering GSA/NBS effort of 1971, but the original Peach Book terms are retained throughout this project. Current international usage may be found in CIB Report: Working with the Performance Approach in Buildings, Publication 64, January, 1982 .

2 While criticizing a building by criteria extrinsic to the building process that produced it may be an enlighting exercise in the architectural connoisseurship, such criticism should not to be confused with evaluation, the essential feedback link in the continuing design-build-evaluate process. There is little realistic hope for improved design without systematic evaluation traceable to clearly articulated design objectives. 


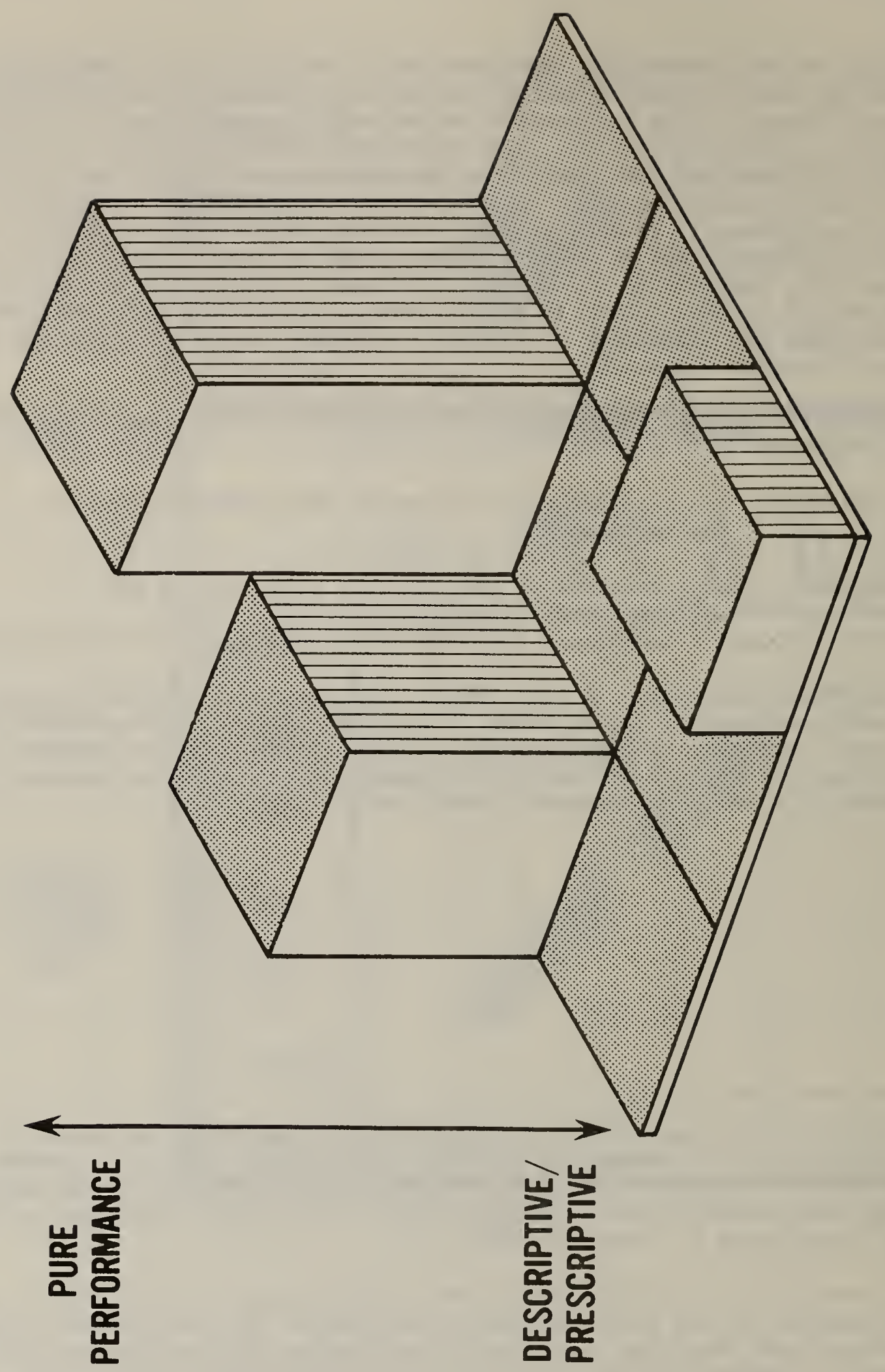

Figure 2.3 Ranges in performance potential 


\section{DOCUMENTATION: EVOLUTION OF THE BUILDING SYSTEMS PROGRAM (BSP)}

The previous section of this report described the intended differences between the BSP and the conventional sequential approaches. But the BSP itself underwent many changes from its inception in the early 1970 s to 1 ts termination about 10 years later. The section that follows reviews the elements of the BSP as they evolved during that decade of experiment.

\subsection{CONSTRAINT AIMS, CHANGING METHODS}

The BSP evolved continually during its life, but it never deviated from the main pursuits of user-oriented, performance-specified, life cycle costcontrolled procurement of flexible interior systems for federal office buildings. While these ends were constant, the means were constantly changing. The single best way to read how the BSP evolved is to analyze carefully the content of the several editions of the performance specification and a few other of the elements comprising the basis of award (figure 2.1). This section analyzes the differences among introductory sections of all published editions of the Peach Book. Later phases of the current project will examine in detail the changing technical content of the System Performance Specification segments of the several editions of the Peach Book.

The introductory sections are analyzed first because they reflect the broadest, most inclusive view of the BSP and the goals it sought. The subdivisions of these sections address the "process" concerns of the BSP, while the System Performance Specification, to be analyzed later in the project, addresses the "product" of the BSP.

The organization of the introductory portions of the Peach Book itself changed over time, making a strict section-for-section comparison difficult, if not impossible. Nevertheless, reading these portions of the several Peach Books in rapid succession reveals a definite shift in tone: the initial Peach Books were full of missionary zeal, proselytizing in behalf of higher quality buildings delivered at lower costs within shorter schedules; but the Third Edition was pure procurement.

The BSP goals were further specified in all the editions into design objectives by means of a thorough-going application of the performance approachl. Full development and implementation of the performance approach would, argued the early Peach Books, liberate the design imagination of the system offerors. The federal officials responsible for BSP pointed out that the size of the initial federal procurement and the sales to the private sector office construction market that were expected to follow would persuade the manufacturers of building products to invest the necessary developmental funds needed to "qualify" a

1 A useful guide to this approach based on experience in several countries since the pioneering GSA/NBS effort is CIB Report: Working with the Performance Approach in Building, Publication 64, January 1982, available from CIB in Rotterdam, Netherlands. 
system. The result would be a technological glant step forward for the bullding community with the Federal Government in the vanguard.

The Third Edition of the Peach Book (November 1975), however, told the same story but in a very different way. No more rhapsodic preaching: the Third Edition is couched in the guarded and precise language of government procurement policy! Does this signify that the great innovative thrust had been spent by the time of the Third Edition? Such a Judgment would be premature at this stage of the BSP assessment. It is equally plausible, for instance, that the earlier, innovative thrust succeeded and had been so thoroughly absorbed into the Industry mainstream with whom the government was now dealing that exhortations to innovate would have been preaching to the already converted. While that determination cannot be made with finality at this point in the project, there are two indications that the "routinization of innovation" hypothesis may be the correct interpretation of the "preaching to procurement" changes in the Peach Book's tone. Both indications relate to the BSP process rather than to its physical performance.

First, the information flows and reporting relationships of the principal participants, already different from roles in the sequential system, changed markedly from the Serles I bullding projects (started in September 1971) to the Series III (begun in November 1975). The shifts that occurred were from an intensely interactive, collective decisionmaking network integrated by an Executive Architect/Engineer in a central information management role in Series I towards the hierarchical arrangement (particularly with respect to the system offeror) more typical of conventional construction contracting. The Series I and Series II arrangements are illustrated in figures $3.1 \mathrm{a}$ and $3.1 \mathrm{~b}$ respectively. Not only did the organizational relation shift toward a traditional deployment, that deployment actually became a part of the PBS's instructions to prospective participants. Whereas, the relations illustrated in figure 3.1a evolved "naturally" from the actual experience of implementing the precedent-setting Serles I bullding process, by the time Series II was undertaken the managerial precedent was sufficiently routinized to permit its inclusion in the Peach Book itself as an operating procedure expected of all successful bidders. That certainly supports the "routinization of innovation" hypothesis.

The second indication supporting that hypothesis was the gradual shifting in the amount of space that the several editions of the Peach Book assigned to the introductory topics. The Peach Book sections discussing goals and the process and management phllosophy of the BSP were reduced from 90 pages in the First Edition to 40 in the Third Edition. The more technically-oriented sections addressing general requirements and procurement, on the other hand, grew from 63 to 102 pages between the initial and last publication of the Peach Book. The shifts are recorded in table 3.1. Moreover, the later editions made greater use of diagrams to convey very explicitly what had been introduced verbally and in a general way in the earlier editions. The map of information flow in figure $3.1 \mathrm{~b}$ came from the Peach Book but the flow in figure 3.la grew organically out of the work itself and was mapped "after the fact." 


$$
\begin{gathered}
\text { Series I Projects } 1 \\
\text { (September 1971) }
\end{gathered}
$$

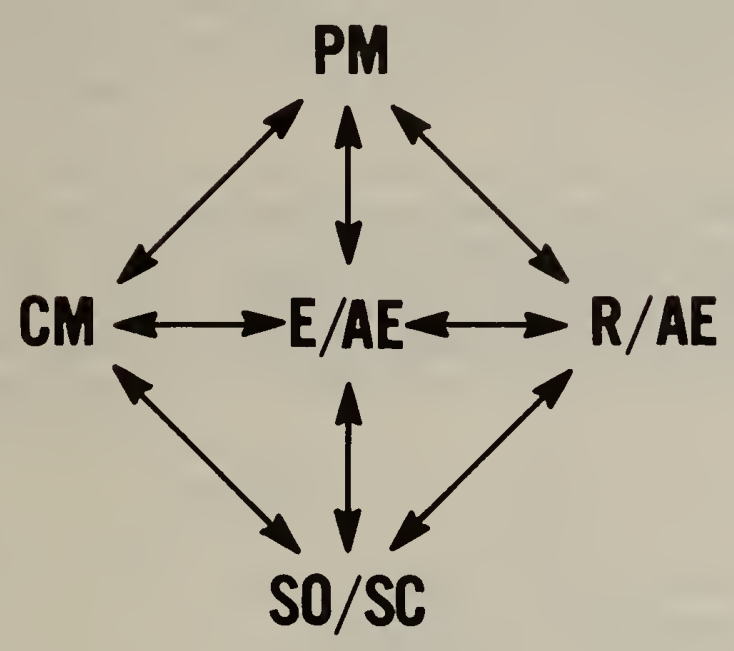

\author{
PM Project Manager (GSA) \\ C'M Construction Manager \\ $\mathrm{E} / \mathrm{AE}$ Executive Architect/Engineer \\ $\mathrm{R} / \mathrm{AE}$ Regional Architect/Engineer \\ So/SC System Offeror/System Contractor
}

\author{
Series II $\stackrel{b}{\text { Projects }}{ }^{2}$ \\ (November 1975)
}

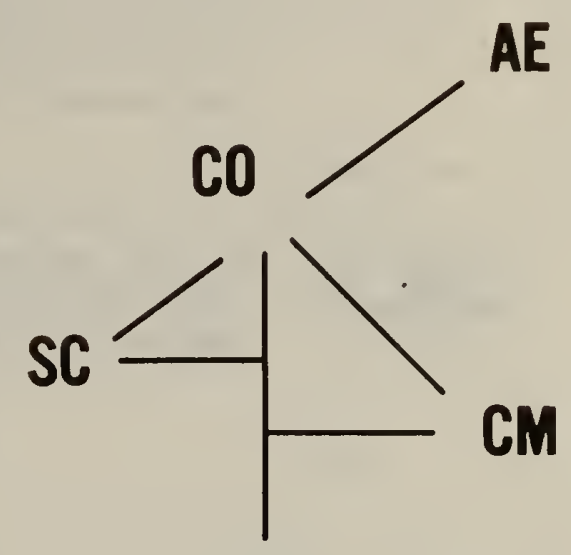

so

\footnotetext{
1 From the Leo A. Daly (unpublished) Report to PBS, The Systems Approach for Building Acquisition.

2 From Peach Book, Third Edition, November 1975, p. 89.
}

Figure 3.1 Information flows and reporting relationships at the beginning and the end of the BSP 
Table 3.1 Summary of Changes to the Introductory Sections of Each Edition of the Peach Book

\begin{tabular}{|c|c|c|c|c|}
\hline $\begin{array}{c}\text { Section } \\
\text { Addressing } \\
\end{array}$ & $\mathrm{PB}: 1$ & $\mathrm{~PB}: 1 \mathrm{R}$ & $\mathrm{PB}: 2$ & $\mathrm{~PB}: 3$ \\
\hline Goals & $\begin{array}{r}\text { Exhortations to enha } \\
\text { Critique of current } \\
\text { tion of new concept } \\
\text { mance approach to } \\
\text { and systems thinkin } \\
19\end{array}$ & $\begin{array}{l}\text { me quality } \\
\text { methods and deriva- } \\
\text { eeting user needs } \\
\text { g. }\end{array}$ & $\begin{array}{l}\text { Toned down expla- } \\
\text { nation. Critiques } \\
\text { reduced. }\end{array}$ & $\begin{array}{l}\text { Deleted exhortations } \\
\text { but retalned primacy } \\
\text { of user needs, ini- } \\
\text { tiated prorurement } \\
\text { steps sor } \\
\text { "prequalification". }\end{array}$ \\
\hline $\begin{array}{c}\text { Process and } \\
\text { Management }\end{array}$ & $\begin{array}{l}\text { Introduces Two-Step } \\
\text { contract is set for } \\
\text { Multiple contracts }\end{array}$ & $\begin{array}{l}\text { procurement as formal } \\
\text { system installation } \\
\text { of out-of-system work }\end{array}$ & $\begin{array}{l}\text { method. A single } \\
\text { an all buildings. } \\
\text { at each building. } \\
+ \text { diagrams }\end{array}$ & $\begin{array}{l}\text { Only systems passing } \\
\text { Step One invited to } \\
\text { b1d. Each BSP } \\
\text { bullding was to be } \\
\text { b1d separately. } \\
\text { + diagrams }\end{array}$ \\
\hline $\begin{array}{l}\text { General } \\
\text { Requirements } \\
\text { pages }\end{array}$ & 30 & $\begin{array}{l}\text { Introduced standard } \\
\text { building operating } \\
\text { procedure and clari- } \\
\text { fied items in fig- } \\
\text { ure 2. }\end{array}$ & $\begin{array}{l}\text { Introduced concept. } \\
\text { of "rates of } \\
\text { change" to specify } \\
\text { flexibllity in } \\
\text { shifting partitions. }\end{array}$ & 43 \\
\hline $\begin{array}{l}\text { System } \\
\text { Procurement }\end{array}$ & $\begin{array}{l}\text { PBS spells out evalu } \\
\text { contractual require } \\
\text { as shown in figure }\end{array}$ & $\begin{array}{l}\text { lation criteria for sys } \\
\text { ments among the partie } \\
2.1 . \\
\text { Language clarified } \\
\text { throughout. } \\
40\end{array}$ & $\begin{array}{l}\text { tem selection and } \\
\text { Basis of award } \\
\text { meC confined to } \\
\text { mechanical equip- } \\
\text { ment maintenance } \\
\text { cost. Drops jani- } \\
\text { torial services } \\
\text { from specification } \\
\end{array}$ & $\begin{array}{l}\text { [System offerors } \\
\text { licensed technolo- } \\
\text { gies to smaller } \\
\text { flrms, allowing } \\
\text { them to bld on } \\
\text { subsystems.] }\end{array}$ \\
\hline
\end{tabular}




\subsection{RESPONSES OF THE SYSTEM OFFERORS}

Several scores of vendors expressed interest in the BSP procurement. Nine consortiums of building product suppliers, designers (architectural and engineering), and contractors submitted Step One technical proposals in response to the initial GSA solicitation; of these three were deemed qualities to bid the Series I (Philadelphia, Chicago; Richmond, CA) projects and only two submitted price proposals. In Series II (Baltimore; Woodlawn, MD), only three consortiums submitted Step One technical proposals; and in Series III, two Step One technical proposals were received.

The principal variation in the technical approaches of the Series I offerors was in the structural systems: two proposed steel-framed systems and one, concrete. Further distinctions among the offers approaches will be presented later in this project after more participants will have been consulted. Also, the project will later attempt to Identify reasons for the apparent reluctance of the prospective offerors to participate in the BSP. 


\section{DOCUMENTATION: HOW GSA/PBS SPECIFIED OFFICE BUILDING PERFORMANCE}

\subsection{SELECTING BUILDING ATTRIBUTES}

Bulldings may be described in as many ways as there are ways of knowing them: as physical objects; as relfications of socially-valued meaning-including psychological, economic, and symbolic meaning; and as objects built to achieve specific, operational purposes. The BSP, as chapter 3 describes, placed primary emphasis on the cost effective provision of the "quality" of spaces required for efficlent conduct of federal offlce functions rather than on detailed descriptions of the "manner" in which space was to be used. The qualities of these spaces were defined by a careful characterization and specification of the federal office occupants' needs for environmental support. These user requirements were drawn out from user's representatives, including managers, in a manner more meticulous than previouslyl and then, to liberate the designer's Imagination and to stimulate technical innovation, to describe those desired qualities in performance terms. This led to the identification of the seven attributes of the office environment 1llustrated in figure 2.1 . These seven attributes, of course, would also be desirable in private sector offices as well, so that any combination of subsystems capable of producing environments with these attributes would find a much wider market than the Federal Government alone.

The process of selecting only seven attributes was a long and deliberate one. As early as December, 1965, the NBS Institute for Applied Technology (predecessor of the National Englneering Laboratory) reported to the PBS Commissioner that targets of technical opportunity in new office buildings were the

...need for 1mproved performance-cost benefits for bullding Expandab1lity, Flexibility, and Mainta1nability ${ }^{2}$.

The American and forelgn precedents described in section 2.5 showed that wide areas free from the intrusion of structural columns and superior luminous and acoustical qualities greatly increased the effectiveness of classrooms and NBS indicated that office bulldings would similarly benefit ${ }^{3}$. NBS work on the further selection began with a single staff member in the summer of 1966 and grew to a three-person team plus numerous consulting specialists. Fourteen office bulldings were analyzed in detall and an average of one hundred employees per

1 Two other efforts had been made to draw out from user representatives a very careful specification of user requirements. These were the "Nenk Method" used to build a British Englneers Regiment Barracks at Maidstone, England in 1960 and the SCSD project in Callfornia a few years later. Other precedents are listed in table 2.1 .

2 Building Systems Innovation, p. 7. (Original italics).

3 Bullding Systems Innovation, p. 17 . 
building were interviewed to provide the basis for 1dentifying and characterizing important environmental attributes 1.

\subsection{IDENTIFYING THE BUILDING ELEMENTS}

A theorist could argue that a "pure" performance approach to building procurement 1.8 compromised when categorles of bullding hardware expected to deliver the stipulated performance are identified. But to be operationalized in an actual bullding procurement process, the performance specification must be capable of serving as a contractual link between a building owner and a supplier (whether a manufacturer, fabricator, installer or bullder) of the technologies capable of delivering the required performance attributes.

Moreover, the objectives of the BSP included a specific intent to encourage the American building Industry ${ }^{\prime} s$ technical innovation to a broad class of office bullding design, construction, and operating challenges, and to do so in a costeffective manner. For these reasons, the Peach Book addressed hardware in terms of bullding elements with which the American bullding product manufacturers were familiar. The further question arose as to whether the hardware specification should follow an "open system" approach -- where subsystems would be solicited from Individual suppliers, thus to encourage the interchangeability of components; or a "closed system" approach - where consortlums of suppliers would be Invited to bld already-integrated systems of components. American, Canadian, and English precedents existed for both open and closed systems by the late 1960s. These precedents, summarized in table 2.1, also showed that a range of subsystems could be included in a total package.

The choice between open and closed system ultimately reduces to a trade-off between freeing the designer to reach functional optimality or imposing on designers such constraints as are needed for deliverability, reliability and economy. On the one hand, open systems offer for the designers of a specific bullding freedom to choose from among a great variety of standardized parts and allowing those designers to assemble one of a very large number of theoretically possible permutations of those parts on specific site in a uniquely optimal way. Closed systems, on the other hand, strive for maximum degree of subsystem integration with greater assurance of total system reliability and cost control, relinquishing some local designer autonomy and system optimization in the bargain. Presented with this dichotomy, GSA, it appears, struck a third choice between the two poles. That cholce achieved some important BSP objectives but also increased appreciably the operational difficulties of the program. GSA chose to treat the total federal office building and its site as an open system while treating the interiors of the typical office floor as a closed system. GSA parlance for this composite method: "Out-of-System" (OS) and "In-System" (IS). Siting, foundations, exterior envelope, circulation and special purpose spaces (including vertical utility cores, lobbies, and auditorlums) and primary energy conversion equipment were handled out-of-System

1 Robert Blake "The 'Peach Book' and the GSA" In Answers for the Building Community: Optimizing the Cholces, Industrialization Forum (IF) Occasional Paper No. 3, September 1976, p. 49. 
(OS) by regional architects, engineers, and bullders. These elements were specified, designed and built under conventional sequencing of separate contracts with a single general contractor at each of the six BSP sites.

The composite method's "In-System" portion was comprised of a single closed system of the seven subsystems listed in table 2.3. The In-System (IS) portion for all buildings of a given series was to be bid and awarded as a single total package to be fabricated and installed in each of the not-yet designed os buildings at sites still to be chosen.

The operational difficulties induced by the precise IS/OS split GSA made have not been minimized by any of the BSP's participants and observers. But the efficacy of the particular IS/OS split GSA and its consultants chose must be evaluated both in terms of what were percelved to be important considerations in the early 1970s (when the cholces were made) and then in the light of current knowledge. Prominent among the earlier considerations were:

1) the encouragement of "diversity in bullding plan and exterior appearance and compatibility with regional surroundings 1 , thus avolding the emergence of a single architectural style for federal office buildings." A response to this consideration would be a tendency to define a system of narrower scope, allowing greater autonomy for the regional architect;

2. the continuing managerial goal of minimizing procurement processing while maximizing the degree of cost control. This was sought by investing authority, responsibility, and ultimately, economic and legal liability in a single contracting entity and it evoked a tendency to widen the system's scope. Indeed, this consideration triumphed in Series I where GSA purchased the IS portions of the three SSA Program Centers ( 1.9 million gross square feet) with a single contract; the OS portions, of those three structures, however, required 67 separate purchase contracts) ${ }^{2}$;

3. the aggregated subsystems would need to be diverse enough to induce synergy among the several subsystems and large enough so that cost savings realized from the IS elements would have a recognizable impact on total project cost. This consideration lead to a planned IS/OS split of 40 percent/60 percent

1 Leo A Daly, Case History of the GSA/SSA Project (brief title), p. 35.

2 Report of the Comptroller General, General Services Administrations Use of New Construction Concept for Federal Buildings Not Yet Successful (Washington: General Accounting Office, October 6, 1977). p. 4 . 
of project costs ${ }^{1}$; The Serles I bulldings actually achleved a 28 percent/72 percent 8 plit ${ }^{2}$.

Imbedded In this last choice was the implicit setting of the IS/OS boundary. The specific elements of IS hardware each had to:

- be subject to standardization due to a similarity of design requirements in typical federal office buildings;

- be usable over a wide geographical and climatic range;

- together, make up a considerable percentage of total construction cost;

- be susceptible to technical improvements and/or cost reduction;

- directly influence the user's working environment. This assessment resulted in the seven subsystems listed in the row across the top of figure 2.1.

Elements which would have difflculty meeting these criterla were excluded, and were assigned "out-of-system." Typlcal out-of-system elements are: exterior walls, foundations, HVAC generating and electrical switching equipment and roofing. These are listed in table 2.3.

W1th these considerations in mind GSA and its consultants, having already chosen the user-orlented performance characteristics to be provided by the bullding system, turned to the selection of the elements of hardware that were to deliver the specific performance. Further, while most of these performance characteristics were to come from within the system, other characteristics would by strongly affected by hardware in the bullding fabric but outside that system. Conditioned air is the most consplcuous example of this, especially in the perimeter zones of the typical floors.

The origin of the division of in and out-of-system components is shown in table 2.3 is thus explained. The remainder of this report discusses the 1n-system aspects of the BSP only, except as noted.

1 "Office Building by System", undated GSA brochure prepared by the Leo A. Daly Company and Ezra D. Ehrenkrantz Assoclates joint venture. The Peach Book had estimated that the floor-celling sandwich (FSS)" alone would be 36 percent of project cost. (Peach Book, First Edition, p. B5).

2 "Three government bu1ld1ngs...", Bu1lding Systems Des1gn, October, November, 1974 , P. 4. 


\section{THE FIELD ASSESSMENT PROCESS}

\subsection{INTRODUCTION TO THE ASSESSMENT}

The preceding chapters described the origins and influences on the 1nitiation, development and execution of the BSP, an effort begun in the late $1960 \mathrm{~s}$ and not completed unt1l the end of the 19708. The following chapters describe NBS/CBT's approach to assessing the effectiveness of the BSP in meeting the performance targets specifled in the Peach Book (and not, except in one case, the adequacy or correctness of those targets).

\subsection{SELECTING ATTRIBUTES FOR FIELD ASSESSMENT}

The BSP's performance approach to the procurement of new federal office bulldings is embedded in the 49 cells of the seven by seven matrix 1llustrated in figure 2.1. The 49 1ntercepts occurred in each of three versions of the Peach Book that served as bidding documents during the BSP (ylelding, incidentally, 147 potential starting points for fleld assessment).

While all 49 cells were accounted for in the inltial preprocurement evaluations of candidate hardware systems, fleld tests on all of them would have severely intruded on the bullding and office operations at the $81 x$ BSP sites. Consequently, NBS/CBT nominated and GSA/PBS concurredl in selecting for this study a smaller number of highly significant performance attributes and hardware components. Attributes were sought that:

1) had most impact (positive and negative) or achleving BSP objectives, considered in retrospect;

2) stimulated spontaneous user response (mostly, but not exclusively, compla1nts);

3) prior evaluations found critical to achleving BSP objectives;

4) were Inftially forecast to be the occasion of greater than usual technical advance. Indeed, table 5.1 reveals advances occurred from one edition of the Peach Book to the other;

5) were outwardly obvious to non-speclallst bullding users;

6) would be accessible to the unobtrusive measurement methods planned by NBS; and

7) occupled different places on the performance continuum.

1 Monthly Progress Review, August 16, 1982. 
Table 5.1 Significant Technical Changes Incorporated in Each Edition of the Peach Book and Rationales for the Changes

\begin{tabular}{|c|c|c|c|c|}
\hline Edition & & Significant Changes & & RatIonales* \\
\hline \multicolumn{5}{|l|}{ PB : 1} \\
\hline \multirow[t]{2}{*}{$\mathrm{PB}: 1 \mathrm{R}$} & a : & $\begin{array}{l}\text { HVAC subsystem broadened beyond } \\
\text { local distribution to include } \\
\text { all delivery system except prime } \\
\text { energy converters }\end{array}$ & a : & $\begin{array}{l}\text { greater technical } \\
\text { and commerclal } \\
\text { Incentive for 1ndus- } \\
\text { try participation; } \\
\text { introduce wider } \\
\text { scope for design } \\
\text { trade-offs }\end{array}$ \\
\hline & b : & $\begin{array}{l}\text { redefinition of reporting require- } \\
\text { ments (e.g., express space adjustment } \\
\text { costs in man-hours rather than dollars) }\end{array}$ & $b:$ & greater clarity \\
\hline \multirow[t]{4}{*}{ PB : 2} & & $\begin{array}{l}\text { total revision of acoustical perfor- } \\
\text { mance specifications }\end{array}$ & c: & $\begin{array}{l}\text { Incorporated results } \\
\text { of prototype testing } \\
\text { for Series I bulld- } \\
\text { ings and advances in } \\
\text { the state-of-the-art; } \\
\text { to accommodate } \\
\text { "open plan" approach } \\
\text { to office design }\end{array}$ \\
\hline & d : & $\begin{array}{l}\text { HVAC system to extended to } \\
\text { include perimeter zones and } \\
\text { prime energy converters }\end{array}$ & d : & $\begin{array}{l}\text { too difficult to } \\
\text { sort out inter- } \\
\text { dependent performance } \\
\text { of perimeter and } \\
\text { interior systems }\end{array}$ \\
\hline & & $\begin{array}{l}\text { revision of lighting performance } \\
\text { spectfications }\end{array}$ & e : & $\begin{array}{l}\text { effort made to in- } \\
\text { clude high-intensity } \\
\text { discharge lighting } \\
\text { (to conserve energy); } \\
\text { ESI, a quality mea- } \\
\text { surement replaced } \\
\text { foot candles, a quan- } \\
\text { tity measurement }\end{array}$ \\
\hline & $\mathrm{f}:$ & deleted custodial maintenance & f : & $\begin{array}{l}\text { too difficult to } \\
\text { quantify }\end{array}$ \\
\hline $\mathrm{PB}: 3$ & $g$ : & $\begin{array}{l}\text { formally established "pre- } \\
\text { qualification of systems in } \\
\text { advance of actual need for a } \\
\text { specific bullding project }\end{array}$ & $\mathrm{g}:$ & $\begin{array}{l}\text { an effort made to } \\
\text { shorten length } \\
\text { of building design } \\
\text { phase by decoupling } \\
\text { from systems pro- } \\
\text { curement }\end{array}$ \\
\hline
\end{tabular}

* Rationales Inferred from analyses of GSA/PBS documentation, oral histories, and contemporary accounts in the professional and trade press. 
In consideration of the foregoing factors, NBS/CBT nominated and GSA/PBS concurred 1 in the choice of four attributes for more detalled field assessment.

The attributes and the rationale leading to their selection are summarized in the first two columns of table 5.2. (The third column is discussed in Appendix C.5).

\subsection{THE LOGIC OF FIELD ASSESSMENT}

GSA, under the terms of the BSP, purchased and 1nstalled only those candidate hardware systems whose vendors certifled as having met the Peach Book requirements, criteria, and tests. One objective of the present NBS project is to assess the extent to which those hardware systems are performing after several years of service. The most stralghtforward way to make this determination is to develop counterpart tests for use at the six buildings. Figure 5.1, explained in more detall below, illustrates the overall scheme for doing this work.

Although the matrix structure of 49-cells was retalned through the 1 ife of the BSP, some of the Information within the "requirement", criteria" and "test" categories changed from one edition of the Peach Book to another. Moreover, the "test" category of each cell often referenced not just one, but several interrelated test methods - $s 1 x$ in the case of 1llumination!. These test methods, moreover, were to be applied to unoccupled prototype bullding assemblies as a part of the research and development effort culminating in a massive one-time procurement. The size of the procurement- $\$ 27$ million (in 1973 dollars) for Series I, for Instance--justified the relatively highprecision measurements that were made and repeated, when necessary, under closely controlled conditions in prototypes that, in Series II, cost $\$ 100,000$ (In 1975 dollars)2. This is a sultable procedure for prototype testing, but testing in the fleld under service conditions presents an entirely different measurement problem for which figure 5.1 offers a more appropriate approach.

NBS/CBT bullding researchers examined the Peach Book-designated procurementprototype tests of the four performance attributes of interest and, using their professional judgement, determined which of the prototype methods were sultable for field use. Where none was sultable, then the researchers identifled standardized field test methods that could produce approximate measurements of the relevant indicators of performance. In other words, the NBS/CBT technical specialists identified test methods that were counterparts to an not replications of the Initial prototype tests of the Peach Book.

Where no standard methods none were avallable, then NBS/CBT proposed developing new methods, but GSA/PBS determined that to be beyond the scope of the current

1 Monthly Progress Review, September 17, 1982.

2 Personal communication from in manager in the jolnt venture awarded the Series II procurement. 
Table 5.2 Building Performance Attributes Selected for NBS Pleld Measurement

\section{Acoustics}

- Cited as critical in previous GSA and GAO evaluations : attribute, demonstrates the importance of the interdependence and total integration of the system element8." Daly Case History, p. 99.

- Totally revised between $P B: 1$ and PB:IR to incorporate results of prototype testing of Ser1es I buildings and advances in the state-of-the-art; and to accommodate growing interest in "open plan" approach to office design. "...acoustics, perhaps more than any other

- Surveyor recorded on check $118 \mathrm{t}$ qualitative judgments of system component's ut1lization and acoustic performance.

- Conduct sound level measurements (Awelghted mean levels) at worker's normal ear-height.

- Protocol differs sharply from Peach Book test, but 18 appropriate for about $90 \%$ of BSP occupied space and $95 \%$ of BSP population

- Instrument to comply with ANSI S1.4-1971, Type 2 standards

- F1ve of six Peach Book lighting tests are analytic methods based on calculation, not directly field measurable as specified.

$P B: 2$ revised to 1) substitute background and task lighting for uniform illumination; 2) adopt Equivalent Sphere Illumination (ESI) methods for measuring lighting quality; 3) accommodate high-intensity discharge lamps.

- Only the "Uniformity" requirement 18 amenable to the Peach Book - specifled field test, using an illuminance meter.

- Measure Illuminance level and contrast rendition to approximate a direct measu rement of ESI.

- Instrument: $\mathrm{SH}$ and G Contrast/ESI meter with reported values noted as "approximate"

- Adapt method from 1981 IES Lighting Handbook (Reference Volume) flgure 4.23 to measure "staggered row" installation.
Conditioned Air

- Cited as critical in GSA and GAO evaluations: GSA June 1976 Task Force Report and GAO October 1977 Report (p.41).

o PB:2 enlarged scope of HVAC system to incorporate "in system" the 15 feet deep perimeter zone previously conditioned by the "out-of-system" building components.

- Emergence as factor contributing to occupational safety and health issue of indoor air quality.

- Dispute over adequacy of test method and qualifications of testing organizations (September 1976 GSA fact sheet).
- Air velocities in pilot test were so low that two different state-of-the-art hot wire anemometers falled to stabilize after the prescribed 1 minute.

- Instrument method: conform with Air Diffusion Council Equipment Test Code 1602 (current version: R4) ANSI/ ASHRAE 55-1981, Thermal Environmental Conditions for Human Occupancy
Planning

- GSA staff estimates that degree of flexibility is generally "overspecifled".

- Cost effectiveness of flexibility increasingly questioned by building researchers Construction Engineering Research Laboratory (Department of the Army, Corps of Engineers, BOSTI, Buffalo, NY: and the Swedish Building Research Institute). the Swedish Bullding Research Institute).

o $P B: 2$ differentiates rates of change for each subsystem, treating change probabilistically.

$\mathrm{PB}: 3$ revised change rates.
- Document actual changes by tabulating Reimbursable Work Authorizations (RWA's) in GSA field of fices.

- Contrast actual change rates with rate of change factors found in table 1 , Peach Book, Third Edition, amendement 1, Apr11 1976, p. G5.13.

- Supplement documented changes with independent recall of bullding operations staff experience. 


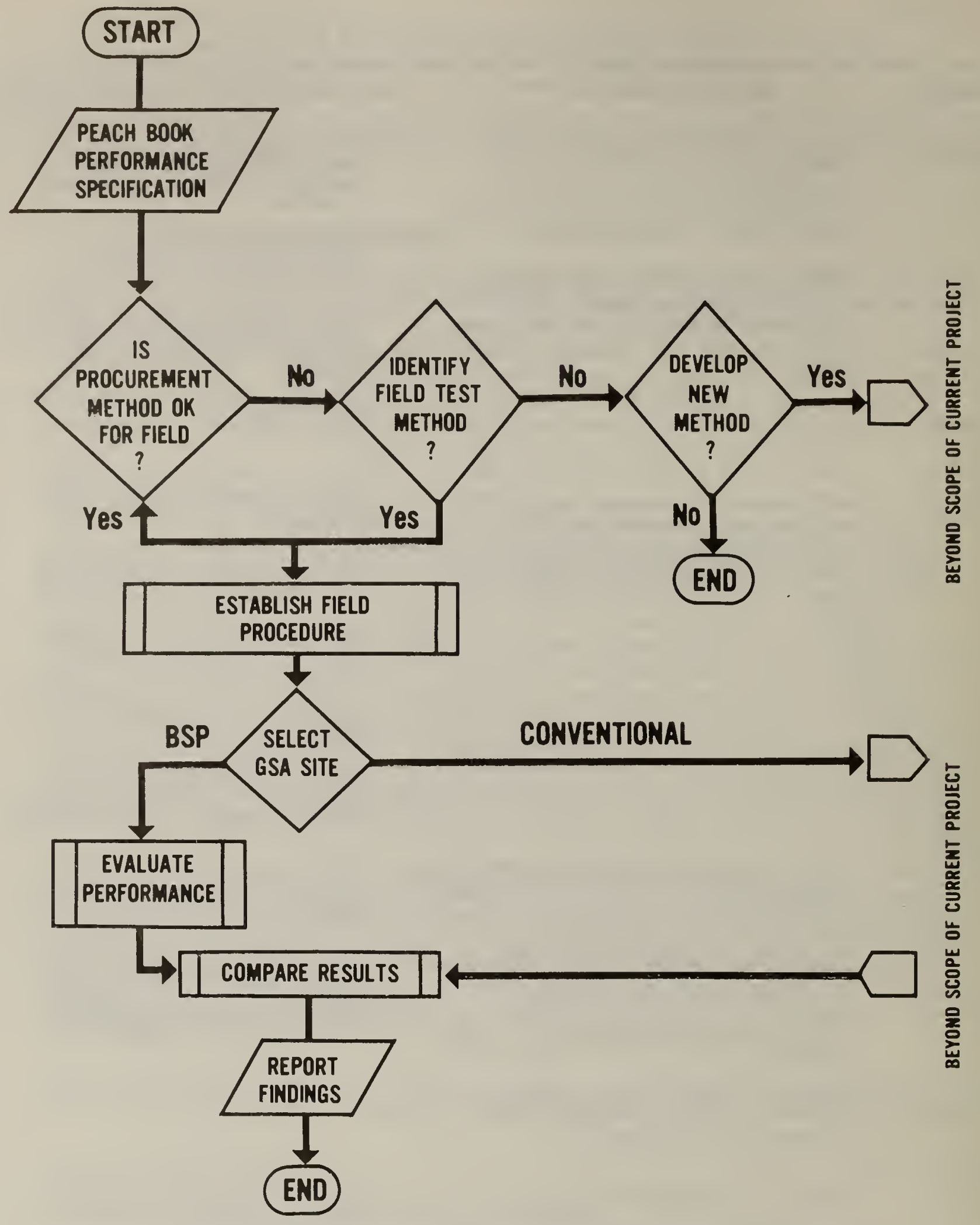

Figure 5.1 Logic of field assessment 
profect, although sultable for consideration at another point in the NBS/GSA cooperative bullding research program. Th1s forced the NBS/CBT specialists to adapt existing methods -- some not yet fully standardized -- to the perposes of the current project. (These methods, both standard and 1mprovised are 11sted in the third column of Table 5.1 and discussed in Appendix C.5.

With measurement methods 1dentified, field procedures were developed. These procedures and methods were to have been applied to both the six BSP building and a number of counterpart GSA buildings of approximately the same age and design but built varying the sequential method of conventional construction and traditional Federal procurement specifications. The results of the two sets of assessments were to have been compared to further isolate the distinct differences between the two methods of bullding procurement but GSA/PBS also deferred this aspect of the work to a later time.

Measuring occupled buildings during the workday requires the use of unobtrusive physical and behavioral measurement methods. To this end, NBS/CBT plans to perform 1ts measurements using portable and, where possible, handheld instruments and requiring no interruption of normal office and building management practices. In fact, the closer to normal these practices remain during data collection, the more representative and accurate will be the assessment. These field measurements are scheduled for early 1983. 
The Series I and Serles II BSP procurements added to the federal office bullding stock 1.880 and 1.997 million gross square feet, respectively. Impressive as these numbers are, however, GSA/BBS' portion of the U.S. construction market 1s, to use Business Week's term, "minusculel." Nevertheless, the Peach Book stimulated interest and "spurred intense competition among some glants of the construction industry. Business Week attributed this wider interest in the BSP procurements to two factors: 1) the scope the performancebased, Iffe cycle cost procurement procedure gave for technological innovation; and, 2) the bellef among some suppliers that innovations ploneered and tested in the BSP would be transferable to the much larger private sector office bullding market. This section of the report describes how those hoped-for effects w111 be measured.

\subsection{CHARACTERIZING THE INNOVATIVE ELEMENTS OF THE BSP}

The BSP Introduced two kinds of changes to the federal office bullding stock: first, the bulldings themselves were to be designed with the users needs as the primary referent for all performance specifications; second, those performance specifications were to be realized using procurement procedures that were themselves Innovative. In short, the BSP attempted to demonstrate the efficacy of product and process innovations.

The earlier chapter of this report reviewed the origins of these changes and described how they were conveyed to prospective bidders via the opening sections of the several Peach Books. A revlew of the Peach Books and of contemporary accounts in the professional press as well as GSA and GAO documents revealed the two kinds of innovations 11sted in table 6.1 , process and product.

\subsection{MEASURING THE BSP's OUTCOMES}

The outcomes, positive and negative, of the BSP were many and varied. S1x bulldings were bullt and have been continually occupled since their completion and their success in meeting administrative and economic objectives have been addressed elsewhere, notably by GSA itself and by the General Accounting office. In contrast, the present project focuses primarily on measuring the technical performance of selected bullding elements under service conditions. Most of these are relatively stralghtforward assessments because the Peach Books clearly, and often quantitatively, expressed the technical performance criteria to be met. Objective test methods for determining compliance with these criterla can be identified; they are often in the form of clearly documented voluntary standards. But measuring the larger impacts of the BSP, or any other program demonstrating Innovations for possible wider commercial adoption, presents a very different problem. Methods for measuring these effects are, compared to the measurement of technical results, still in the developmental stage. This section of the report, therefore, recommends methods that, while necessarily more tentative, have been widely discussed among evaluation researchers.

1 "All eyes are on the GSA's 'upkeep' contacts", Business Week, June 21, 1976. 
Table 6.1 Outcomes of BSP Process and Product Innovations

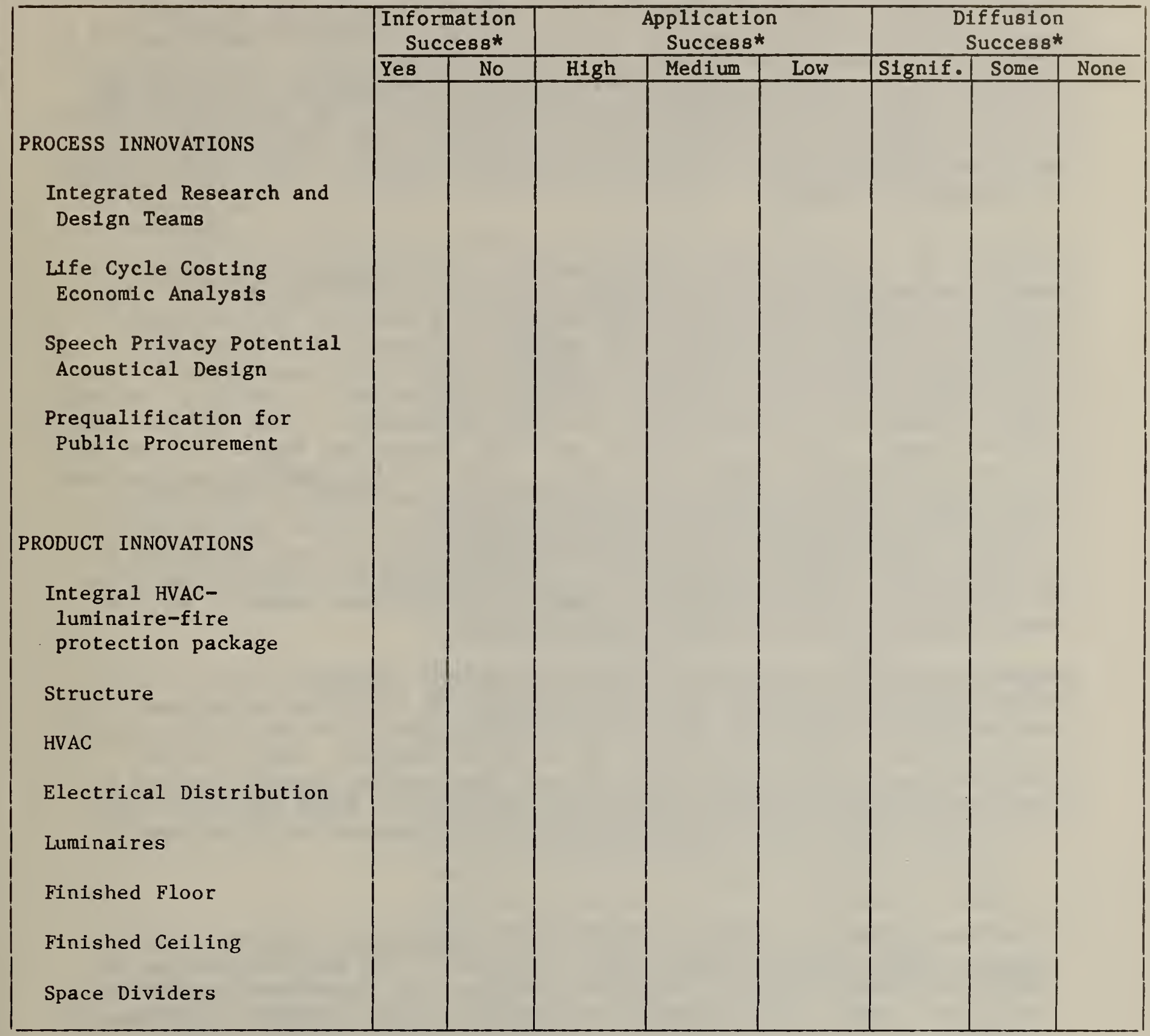

* Terms defined in section 6.3 of the text. 
Demonstration projects are often undertaken by the government to reduce private-and public-sector uncertaintles about the benef1ts and costs to society of new technologies. And whlle the BSP was, first and foremost, a bullding procurement effort, the great attention pald to BSP outside of government was probably due to the $11 \mathrm{kl}$ lhood of particlpants galning the compet1tive advantage of early access to uncertainty-reducing technical information. The BSP part1clpants assured themselves access to this information in one of two ways: f1rst, the Inftial GSA procurement was large enough to offset a large part of a firm's cost of developing 1 ts own, proprietary knowledge and, second, the exchange of information required for 1ntegrated system design would bring any particlpant rapidly to the state-of-the-art knowledge of the other participants. Th1s was a strong Incent1ve for some, but for others, the cost of entry mostly an investment in developmental englneering studles -- was simply too high for the expected return ${ }^{2}$.

The true test of a bullding demonstration's value 18 not solely or even primarily the extent to which the technologies incorporated in the demonstrat1on are subsequently adopted for wider use in the bullding community. Adopt1on 1tself 18 only one of several conquences of a prior and more valuable outcome of a technical demonstration; namely, the reduction of uncertainty surrounding a decision on bullding technology. Uncertalnty may appear in one, or a combination, of several forms: technical uncertalnty -- asking 1 the technology 18 feasible for a particular use; cost uncertainty -- what are the requirements in terms of cap1tal investment, operating expense and expense of fabricat1on and 1nstallation; demand uncertainty - what are the benef1ts accruing and what value do varlous segments of the bullding market place on those benefits; and, finally, institutional uncertainty of two kinds, 1nternal and external: internal, meaning within the organization accommodating the new technology (1n the present case, $\overline{G S A / P B S}$ ) and external, meaning among the organizations with whom GSA/PBS has traditionally dealt (namely, the bullding community and the tenant agencles sheltered in the BSP structures).

To the extent that uncertainty 18 reduced or somehow mitigated, then to that extent subsequent technical and pollcy decision are 11 kely to be 1mproved. In some cases, those declsions may favor wider diffusion of the innovative methods; In other cases, traditional methods may be found superior. But in elther case wiser declsions are more likely to have been reached because they can be based on documented experience rather than confecture. Since the BSP' 8 object1ve 1ncluded "significant Innovations...1n the management and techniques of

1 Important sources are Walter S. Baer, et al., Analysis of Federally Funded Demonstration Projects: Final Report, prepared by the Rand Corporation for the Experimental Technology incentives Program, U.S. Department of Commerce R-1926-DoC, Apr11 1976; Struen1ng and Gittentag (eds), Handbook of Evaluation Research; and Evaluation Rev1ew: a Journal of Applled Soclal Research (b1-monthly).

2 So commented Sheldon Stelner of the New York Clty engineering firm of Flack and Kurtz, quoted in Bus1ness Week, June 21, 1976. 
construction"1 and "final goal [of] increasing the effectiveness of the bullding industry" 2 then the broader test - contribution to the reduction of uncertainty - should be applied first and then, and only then, the conceptually straightforward but practically more difficult task of measuring actual industry adoption of the innovations pioneered in the BSP.

\subsection{THREE TESTS OF BSP' 8 OUTCOME}

The BSP was a building procurement, a demonstration undertaken to produce information to reduce future technical and policy uncertainty, within GSA/PBS, and, in the words of the PBS Commissioner who directed the last BSP procument, an act consistent with the "leadership role of PBS in the building industry". These three roles -- procurement, demonstration and leadership -- suggest the three different, but related tests for the success of the BSP that are here summarized ${ }^{3}$ :

Information Success - if, at its completion, uncertainties are no longer
a barrier to decisions about further adoption of a
technology, (Note, not whether something should
or or should not be done, but, rather, is enough
known to make a competent, responsible decision.)
This result can be indicated with a simple "yes"
or "no".

Application Success - the extent to which GSA/PBS and its advisors are satisfied with the reliability of the innovative system and the performance qualities it delivers. Success here is better measured on a three-part scale: "high" -- if the delivery of specified performance is acceptable and reliable; "medium" -where specified performance is delivered with only minor problems; and "low" - where the project either fails to deliver the specified performance or serious problems of reliability or quality occur.

Diffusion Success - measured by the extent to which the technology (process or product) has, consequent to the BSP and not merely subsequent to it, passed into general use in the corresponding parts of the building industry or (in the BSP case) to other bullding procurement agents of government and their private sector counterparts. This

1 PBS Commissioner's Introduction, $\mathrm{PB}: 3$, not paged.

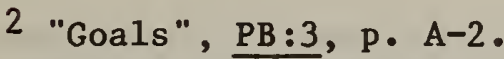

3 The following definitions are adapted from Baer, et al., Analysis of FederallyFunded Demonstration Projects. 
varlable can be calibrated as "significant diffusion" - where consequent diffusion beyond GSA/PBS is self-sustaining; "some diffusion" -where the BSP technologies have been adopted in a few cases, but the process still needs occasional stimulation; and "little or no diffusion" -- where further adoption 18 unlikely without strong and sustained stimulation.

Direct and exact measurement of BSP outcomes on all three dimensions of interest--information success, adoption success and diffusion success-1s possible only with an exhaustive description of the state-of-the-art of office bullding procurement, (1ncluding design and construction) in 1970 before the BSP and the situation at the end of the decade when the BSP 1trelf came to an end. Nelther of these ex1st, and the measurement problem 18 compounded because of the inability to distinquish changes resulting from the BSP 1tself and changes in the state-of-the-art of office design and construction because of other efforts totally unrelated to the BSP. Th1s is a significant consideration since most of the vendors providing bullding components to meet the Peach Book speciflcation were also developing products in response to demands from other parts of the bullding community. Consequently, statements about the outcomes of the BSP and 1ts wider 1mpacts must be, for the most part, approximate and not exact and based on Judgments of knowledgeable people augmented wherever possible by direct, empirical indicators of change.

The systematic solicitation and use of the fudgments of experts in evaluating difficult-to-specify policles or actions has matured dramatically since ploneering efforts of the early 1960sl: methods have 1mproved to the point that a small 1ndustry seems to have grown up based on applications of the Delph1 Method, for 1nstance. A basic requirement for all such studies 18 the 1dentification of numbers of knowledgeable but disinterested and 1mpartial correspondents. But, 1dentifying even a mintmum-sized cohort of bullding professionals knowledgeable enough to provide informed judgments about the technologies assoclated with the BSP cannot be done, 1t seems at this point, without calling on the BSP participants themselves and others who were responsible critics or commentators during the BSP's lifetime.

The NBS/CBT assessment of BSP w1ll 1nterview separately a panel of research correspondents drawn from among these experts. The interview will follow accepted professional practice to maximize the validity of responses.2 While use of a panel of the type indicated may not be the ideal vehicle for a fully

1 The state-of-the-art is documented in Harold A. Linstone and Murray Turoff (eds), The Delph1 Method: Techniques and Applications, (Reading, MA: Add1son-Wesley, 1975).

2 Such practices are discussed in Carol H. We1ss, "Interviewing in Evaluation Research" In Struening and Guttentag (eds), Handbook of Evaluation Research, Vol. I, pp. 355-396. 
object1ve assessment - if one ever were attalnable, wh1ch 1s, to say the least, doubtful - there is at least one moderating factor, the temporal one: sufficient time might have elapsed -seven years since the publication of the last edition of the Peach Book, three since occupancy of the last BSP structure In Norfolk -- so that even deeply-involved competitors and adjudicators, vendors and purchasers participating on the panel may have gained a more even-handed and tolerant retrospective view of the BSP than might have been expected from them in the middle of the venture. But an expert panel's tolerance should not be construed to mean a relaxation of intellectual rigor in reaching judgments. Rather, the opposite 1s required: expert panelists must be chosen for their ability to distinguish between mishaps of execution owing to honest misunderstanding, on the one hand, and misspecification of the conceptual approach of the BSP 1tself, on the other.

\section{CONCLUSION}

The BSP was a multi-faceted enterprise, attempting to innovate in areas of building design, construction management and operations as well as in the government procedures for procuring all these elements. Consequently, a true assessment of BSP's effects must employ multiple strategies and methods. This initial report identffies and explains the several approaches proposed by NBS/CBT to conduct that assessment.

Knowledgeable professionals will provide expert judgements of the effects of the BSP in the wider building community. These judgements will be augmented whenever possible with quantitative indicators of technical change. To gauge the immediate outcomes of the BSP the NBS reserch team will measure critical performance attributes in the six "system" buildings now in service. The results of these judgemental and empirical assessments will be reported at the conclusion of the assessment project. 

APPENDIX A - SUMMARY OF METRO WEST PILOT RUN

\section{A.1 INTRODUCTION}

Prudent practice In engineering and applied social science recommends that modestly-sized diagnostic explorations should precede a significant and costly full-scale data collection. Measurement approaches, for Instance, should be pretested in an environment representative of the large universe that ultimately will be evaluated. This is done for both administrative and technical reasons: research administrators need to know more preclsely the time staff and dollar costs for collecting fleld data and the research team must assure itself that essential phenomena are captured in the measurement protocols. For these reasons, NBS/CBT determined early that the measurement's methods tentatively selected for use in the BSP assessment be fleld tested at a BSP site. For reasons of economy, the Social Security Administration (SSA) Metro West Building in Baltimore, Maryland was the site of the survey pretest.

\section{A. 2 SSA METRO WEST}

The SSA Metro West Bullding intended to serve as a "western gateway to Baltimore" as well as the workplace for the 4000 SSA employees, 18 the largest single building in the BSP, accounting for about one-third of the total occupled area contalned in the six BSP bulldings and sheltering nearly 40 percent of the total staff working in BSP structures. (Figures A.1 - A.4 and table 1.1.) While usually large, Metro West is typical in these respects.

- like five of the $81 x$ BSP structures, Metro West is occupied by a single agency;

- like five of the six, Metro West is preponderantly organized in a "pool" arrangement of workstations;

- like five of the six, clerical processing of written information is the dominant activity; and

- as in many offices, electronically-energized video displays of alpha/numeric data are supplanting electro-mechanically produced "black on white" paper tasks with important environmental consequences

An NBS research team visited Metro West on November 4, 1982 to familiarize themselves with the logistics of field measurement in working offices. The NBS team included Mr. Fred Rudder, an engineer in CBT Acoustics Group; Dr. Sam Silberstein, biologist in the CBT Thermal Measurement Group; Dr. Francis $T$. Ventre, senior research architect of the CBT Office of Construction Programs (team leader); and Dr. Robert W. Marans, Director of the Urban Environmental Research Program of the University of Michigan's Survey Research Center (a consultant to NBS with a national reputation in post-occupancy evaluations of completed buildings). Mr. Ted Hattenburg, a physicist in the CBT Illumination Engineering Group, contributed to the team's effort but did not travel to Metro 


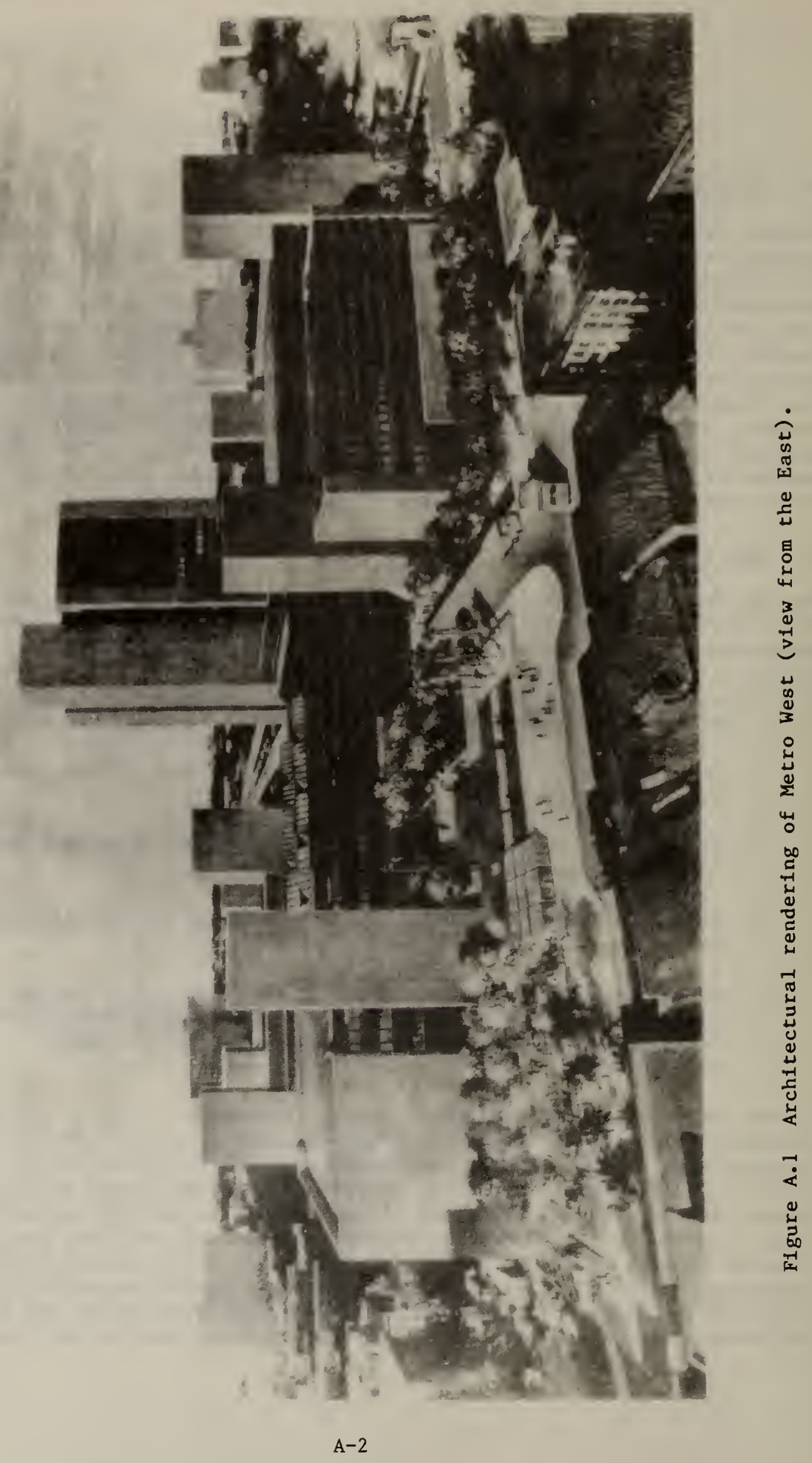




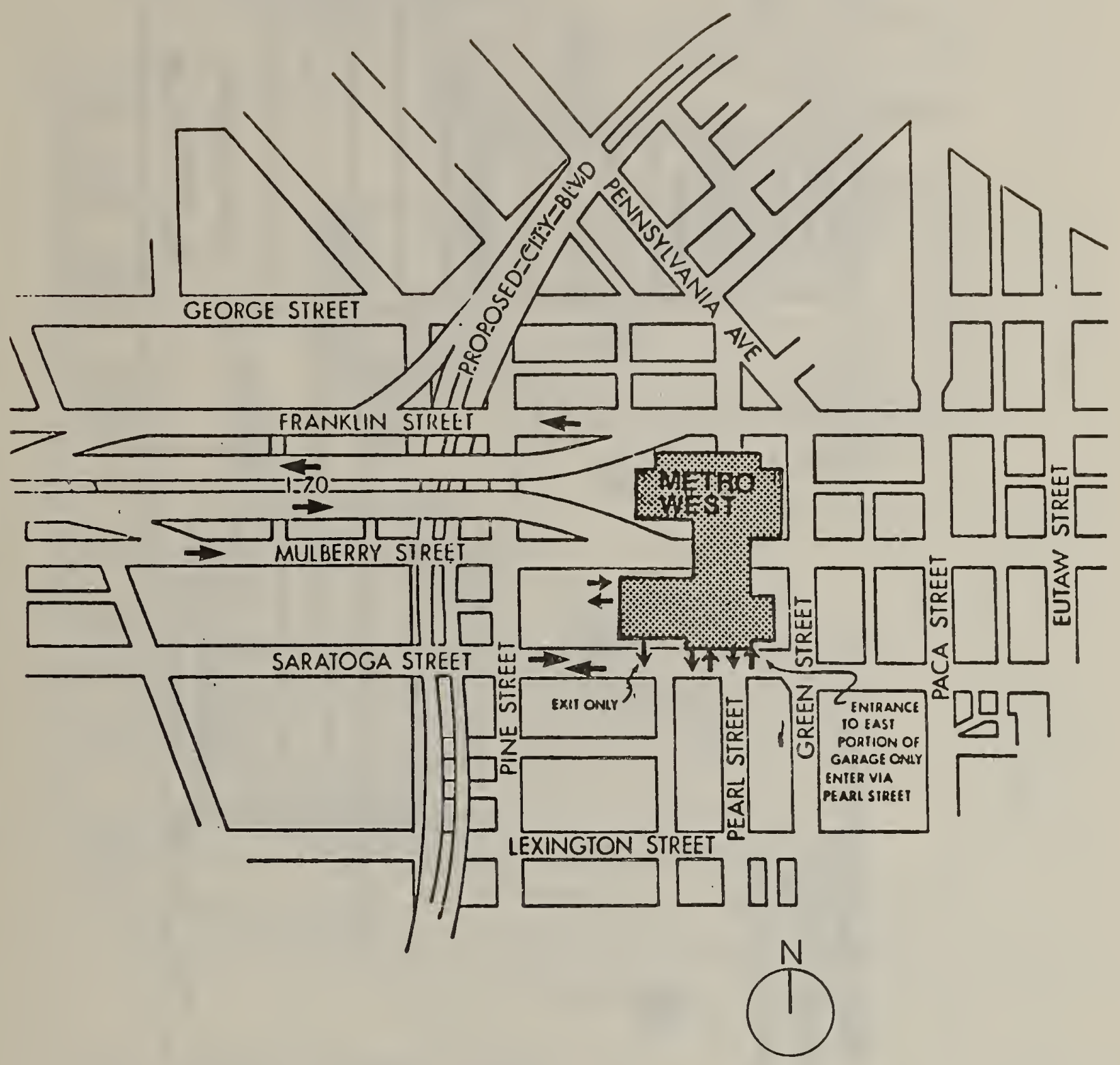

Figure A.2 Location of Metro West 


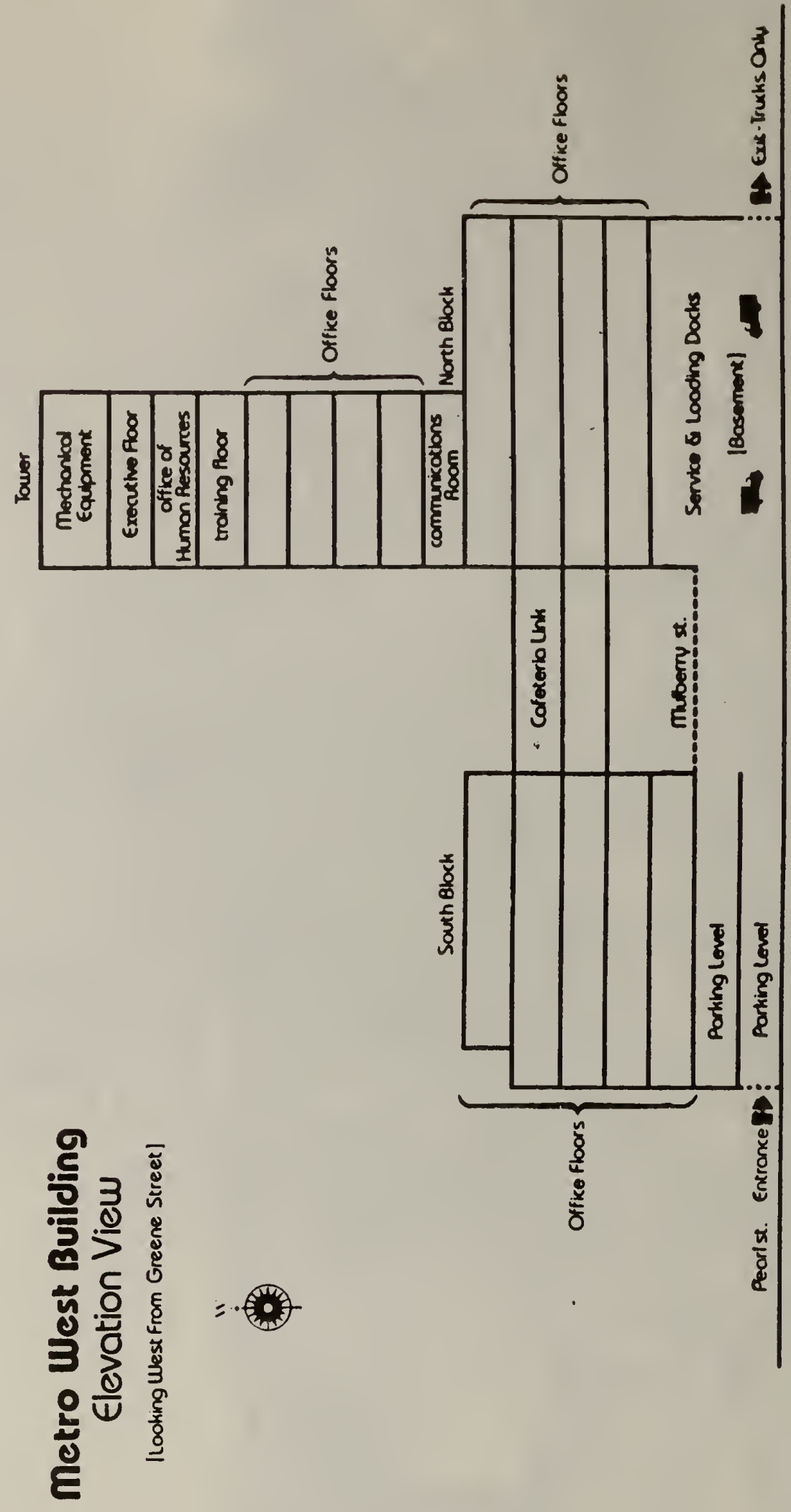

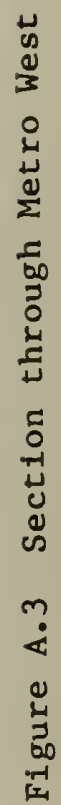




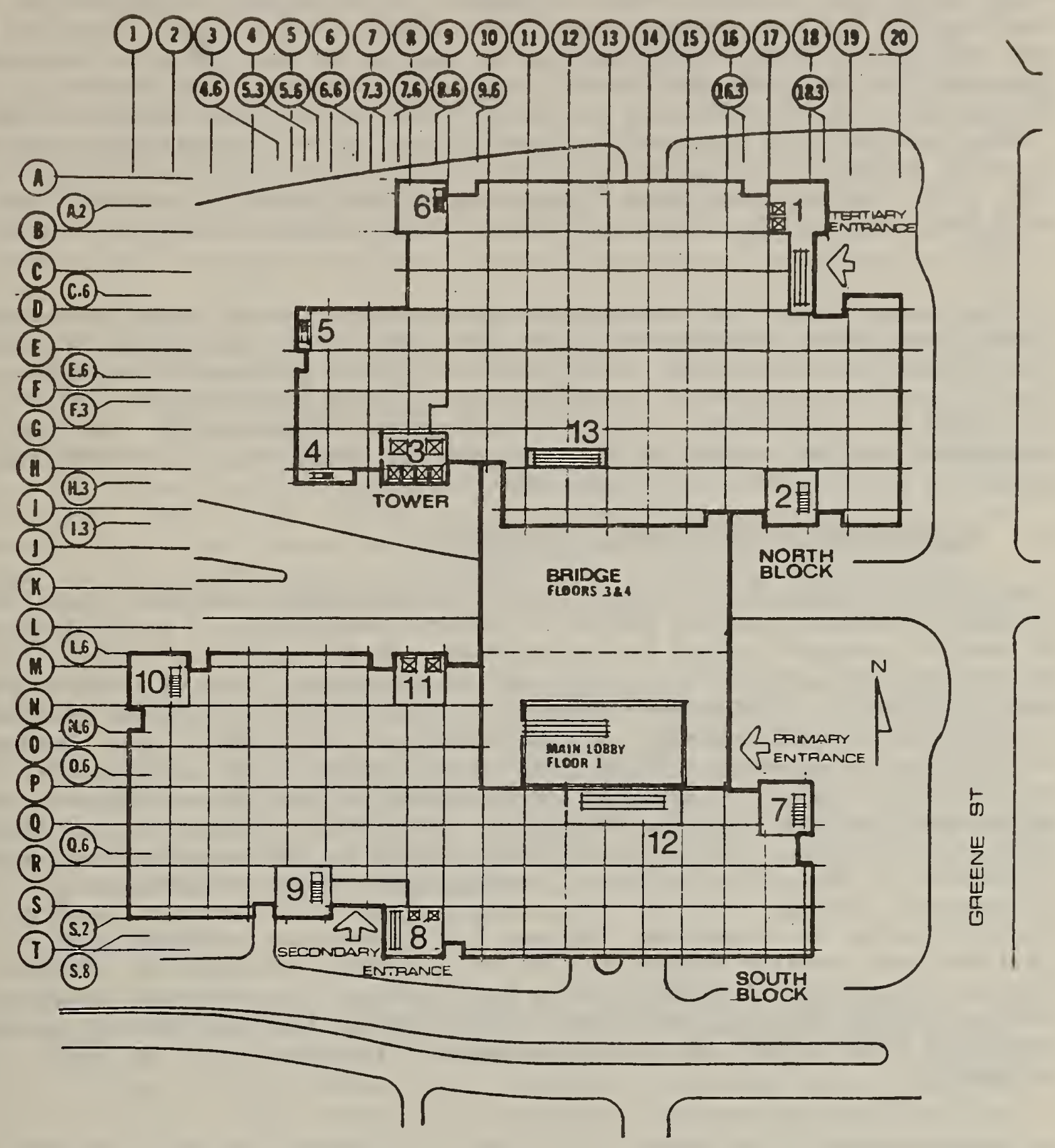

NOTE: Cores are numbered as shown.

Figure A.4 Metro West column, core, and entrance plan 
West. Each member of the team had previously reviewed Peach Book:2, the spec1fication to which Metro West was designed and bullt and each was equipped to make needed measurements. These procedures are documented in appendix C. Resident GSA Bullding manager, John White, distributed a 63 page "BuIlding Data and Information Guide," and orlented the team to the bullding, its uses and occupants and 1mportant design and construction features. The feature introducing the greatest difficulty to operations is the in-system/out-of-system "Interface" but even these difficulties did not affect the activities sheltered directly except for the floors immediately over the open-air parking decks. (Mr. White reported that these floors were not sufficiently insulated from the cold and, consequently, these offices are uncomfortable during the heating season).

of the purely "In-system" segments of the bullding -- flve floors in the south block, four floors in the north block, and elght floors in a tower occupying one-fifth of the area of the north block -- contain no localized problems. These 15 portions accounted for 40 percent of Metro West's $\$ 78,631,833.00$ estimated cost (coinciding exactly with the BSP's target split). Moreover, the in-systems portion accounted for less than its share (only 34 percent) of the project's $\$ 12,805,378.00$ in change order costs 1 .

\section{A.3 MEASUREMENTS OF THE PHYSICAL ENVIRONMENT}

The NBS team measured llluminance (in "raw" footcandles), ambient nolse (In Awelghted decibels), and air motion (in meters/second) from 15 to 19 locations at several scattered points in the building. No measurement of "flexibility" of interior space dimension or services was attempted. Each of these measurement's methods is described in appendix B. Descriptive statistical analyses (measures of central tendency and coefficients of variability) were completed, revealing good agreement with the Peach Book:2 values. The principal purpose of the pilot study is to evaluate the feasibility, utility, and logistics of measurement methods, however, and not the data itself. This pilot indicates that most measures could be successfully applied in field settings with minimal disruption of the office workflow. Logistically, three team members made 10 llluminance readings, 5 sound level readings, and 10 air-movement readings at 5 scattered sites in 15 minutes; the next 8 locations were measured in 24 minutes. This rate was possible because the fourth team member recorded all readings, freeing the readers to concentrate on their meters. An advantage expediting data collection that may be unique to Metro West is that all interior columns there are clearly numbered so that measurement locations could be readily documented.

1 Financial data from GSA/PBS Office of Design and Construction, Design Management Division, Post Occupancy Evaluation: SSA Metro West (PCD 8274011), p. 15. This evaluarion was based on the observations of a visiting GSA/PBS team and on the interviews with agency principals. No physical nor perceptual behavioral measures of elther the environment or 1ts occupants were reported. The evaluation reports illustrations, however, were informative. 


\section{A. 4 FORTUITOUS FINDINGS}

A useful tertiary purpose for pilot testing - In addition to the logistical and technical reasons cited earlier - is the discovery of unanticipated phenomena. This happened at Metro West and influenced subsequent research planning. The team members observed and noted to one another various practices in the occupying agency's management of, or the worker's use of, their 1mmediate, local enviornments. These practices ran counter to the intent of the Peach Book specification that guided the initial in-system designs of the typical floors at Metro West. Agency managers appeared to have converted the movable, head-high acoustical screens into either conventional space dividers or baffles for blocking visual access between management suites and the workforce at large. On other floors, the head-high acoustical panels were placed before west facing windows with otherwise unobstructive vistas extending for miles. In both cases, and in many other cases throughout Metro West, building occupants had vitiated the Peach Book's intricate acoustical performance criteria by not deploying the screens as components of an acoustical conditioning design. That is, rather than using the screens to 1solate noisy equipment or to subdivide vast open offices into smaller, more familiar room-sized compartments, the "line of sight" supervisory philosophy of the agency took precedence. Fortunately, despite this "misuse" of an expressly designed component of an intricate acoustical system (which included absorption in the ceiling and floors, as well as the screen, and augmented by a background white noise generator), the office floors at Metro West remained, acoustically speaking, serviceable.

This finding leads to one of two possible conclusions: either the Peach Book:2 acoustical criteria were too demanding, resulting in wasteful redundancy of acoustical absorption in the BSP spaces, or, and this is equally plausible, such redundancy is advantageous in that BSP spaces remain serviceable even after occupants manipulate important components to meet purposes or needs the building designers might not have anticipated. Further consideration of this subject, which reaches to the heart of design philosophy, is beyond the scope of the present project and is now ended.

\section{A. 5 CONCLUSIONS}

The November 4, 1982 pilot test at Metro West established the feasibllity of measuring a variety of physical phenomena with a minimum description of the office workflow. The great size of Metro West and the fact that the GSA/PBS stock of office buidings contain many large structures made spatial sampling the most efficient and scientifically defensible approach to describing the performance of the BSP inventory. Finally, the number and variety of gross occupant adjustments to the intricately designed bullding systems suggested that numerous robust and even approximate measurements would better serve the 3SP assessment than a smaller number of meticulously exact and, therefore, costly measurements. 


\section{B.1 REPRESENTING THE BSP STOCK}

\section{B.1.1 Why Sampling?}

The post-occupancy evaluations of bulldings that GSA/PBS has conducted or for which it has contracted have not, heretofore, addressed problems of spatial sampling. Sampling is necessary now, however, because the six buildings built under the BSP are relatively large, so large that the 100 percent sampling methods used by NBS on such buildings as the Norris Cotton Federal office Bullding in Manchester, $\mathrm{NH}^{l}$ or the Richard H. Poff Courthouse and Federal Building Roanoke, $V^{2}$ would be unworkable given the resources avallable. The $81 x$ BSP buildings 1lsted in table 1.1 range in size from the 1.3 million gross square feet at Metro West in Baltimore to the .25 million gross square feet in Norfolk Federal Bullding. (In contrast, the Manchester and Roanoke bulldings combined are only slightly larger than the Norfolk building.)

With structures so large, spatial sampling methods are more economical. In order for the sampling results to be credible, however, these sampling methods must incorporate established statistical engineering practices. Spatial sampling is a relatively unexplored area for the combination of building performance attributes with which the BSP assessment is concerned, namely; acoustics, illumination, air movement, and flexibility of interior space division. Consequently, NBS/CBT professional staff directed its attention to an exploration and selective use of statistical sampling and spatial analysis. This effort is justified because at the conclusion of the current effort, GSA/PBS will have for its use, or for the use of its future contractors, an approach to constructing reliable and credible spatial samples from its building stock. This technique should prove especially helpful to GSA because GSA/PBS deals frequently with very large buildings: a mere 9 percent (200 buildings) of GSA/PBS's total number of structures account for half of the building space it owns and operates. GSA staff analysts, using these new techniques, may then more confidently generalize finding from small samples to larger universes.

\section{B.2 APPROACHES TO SAMPLING}

All descriptions of environments, indeed, all perceptions are selective. Humans could not function in this welter of sense-data without making

1 Jacqueline Elder and Robert L. Tibbott, "User Acceptance of An Energy Efficient Office Building -- A Study of the Norris Cotton Federal Office Building, Department of Commerce, National Bureau of Standards, Washington, DC, BSS 130, January 1981 .

2 Jacqueline Elder, George E. Turner, and Arthur I. Rubin, "Post Occupancy Evaluation: A Case Study of the Evaluation Process, Department of Commerce, National Bureau of Standards, Washington, DC, NBSIR 79-1780, July 1979. This carried an evaluation of the Richard H. Poff Courthouse and Federal Building in Roanoke, VA, completed in December 1975. 
selections, attending to some cues while 1gnoring others. The same principal applies to technical surveys of bulldings. The NBS/CBT technical surveys of the BSP bulldings selected, with GSA/PBS concurrence, four bullding attributes for documentation and assessment. But even within this limitation, further refinement is required to assure that a relatively small number of measurements made (small only when compared to the infinity of possible measurement locations in, say, a 500,000 gross square foot structure) can be generalized into a reliable description of an entire bullding. Description is the operative word here, for if GSA/PBS were seeking to explore or define in a tentative way some bullding issues or NBS/CBT were seeking to explore some bullding phenomena, then representative, reliable decriptions would not be needed. But descriptive surveys relying on relatively small numbers of measurements usually require statistical sampling methods in which the probability of a certain bullding element being included in the measured sample must be known in advance of the actual measurement, Indeed, before one chooses the exact site for a measurement. Otherwise, unlversal generalizations from the specific sites would be skewed to over -- represent conditions local to those specific sites.

Some guldance exists for where and with what frequency bullding characterizing measurements shall be made. One widely used method is that recommended by ASHRAE for the "evaluation of thermal parametersl." Table 5 of ASHRAE 55 recommends that thermal conditions (including air movement, the thermal attribute of interest in the current assessment) be measured in office bulldings as follows:

\footnotetext{
"In each zone of a typical floor; at the center of and $60 \mathrm{~cm}(2.0 \mathrm{ft})$ from each side of the control zone and at the center of the space in each zone."
}

Each of the other environmental design specialities (1ighting, acoustics, etc.) 1ssue simflar instructions, which are condensed in section 2 of this appendix. But two large problems remain: no single method is offered for the general question of spatial sampling to represent the joint effect of all attributes over the entire bullding nor has a technical consensus been established for the minimum number of measurement locations required. Here GSA/PBS and NBS/CBT are breaking a new methodological path. These challenges are compounded by the GSA and NBS commitment to complete bullding measurements with minimal interference with the office practice at the $81 x$ BSP sites. W1th this commitment is the Implication of portable and preferably, hand-held Instrumentation.

\section{B. 3 FACTORIAL EXPERIMENTAL DESIGN}

The In-System Interiors of the six BSP bulldings are to be assessed by comparing the performance spectfled in the Peach Books with that delivered at the time the bulldings are measured. Although the Peach Books attempts to create a uniform both planned and unanticlpated environment, variations in the bullding's siting, construction, and use occur. These variations can neither

1 ANSI/ASHRAE 55-1981: Thermal Environmental Conditions for Human Occupancy. 
dominate any subsequent assessment nor can they be ignored. Researchers use sampling methods to control for these varlations systematically. The method used in the present project is to "stratify" each bullding in the BSP building universe into a small number of recognizable subgroups differentiated along dimensions significant to the measurement of bullding performance and then, from each of all possible or plausible combinations of strata, to randomly select one, or preferably two, measurement points1. At each point so chosen, the NBS team w111 measure and record for each parameter extreme values of that parameter (maximum and minimum), some measure of central tendency (usually an arithmetic mean) and some coefficient of varlation to indicate the precision of the measurement indicating the closeness of successive measurements of a single magnitude by repeated applications of the same measurement process 2 .

Table B.1 lists important subgroups of the BSP to be reflected in the sampling. An NBS resarch team nominated these subgroups after a preliminary visit to the SSA Metro West Building described in appendix A. All possible combinations that can be formed among the different levels or subdivisions of the factors quickly becomes a very large number. Consequently, a fractional factorial design is recommended.

Finally, an external device is needed to randomize the selection of the one or two measurement site per station. This is to reduce the likelihood of the surveyor's unintentionally seeking one part of a building from which to take measurements, thus, giving an unrepresentative and inaccurate description of the building under analysis. For instance, a surveyor might unwittingly favor locations adjacent to the building's circulation systems to save time or to choose unoccupled desks further to reduce intrusions into the workplace routine. Systematic error, or bias is, thus, introduced because it is the surveyor's selective perception of the bullding that w111 be measured and not the building itself; consider that only a small fraction of the possible measurement sites are adjacent to the circulation system and that the desk may be unoccupied because a temporary malfunction of the bullding subsystems (say a malfunctioning alr handler) might have made the space uncomfortable. Now it is an entirely different matter if random selection of measurement sites continue to turn up such uncomfortable thus unoccuplable spaces. For these reasons, NBS will follow recommended statistical engineering practices in the BSP assessment. The extended devise used will be a table of random numbers.

\section{B.4 SELECTION IN THE FIELD}

The NBS surveyor w11l ascertain from the building manager the number of In-System floors and the nominal structural bays known to contain each of the office arrangements listed in table B.1.d. Using scale drawings similar to

1 Mary G. Natrella, Experimental Statistics, Handbook 91, U.S. Department of Commerce, 1962, Chapter 11.4.

2 This discussion is drawn from Churchill Eisenhart, "Expression of the Uncertainties of Final Results," Science, Vo1. 160, June 14, 1968, pp. 1201-1204. 


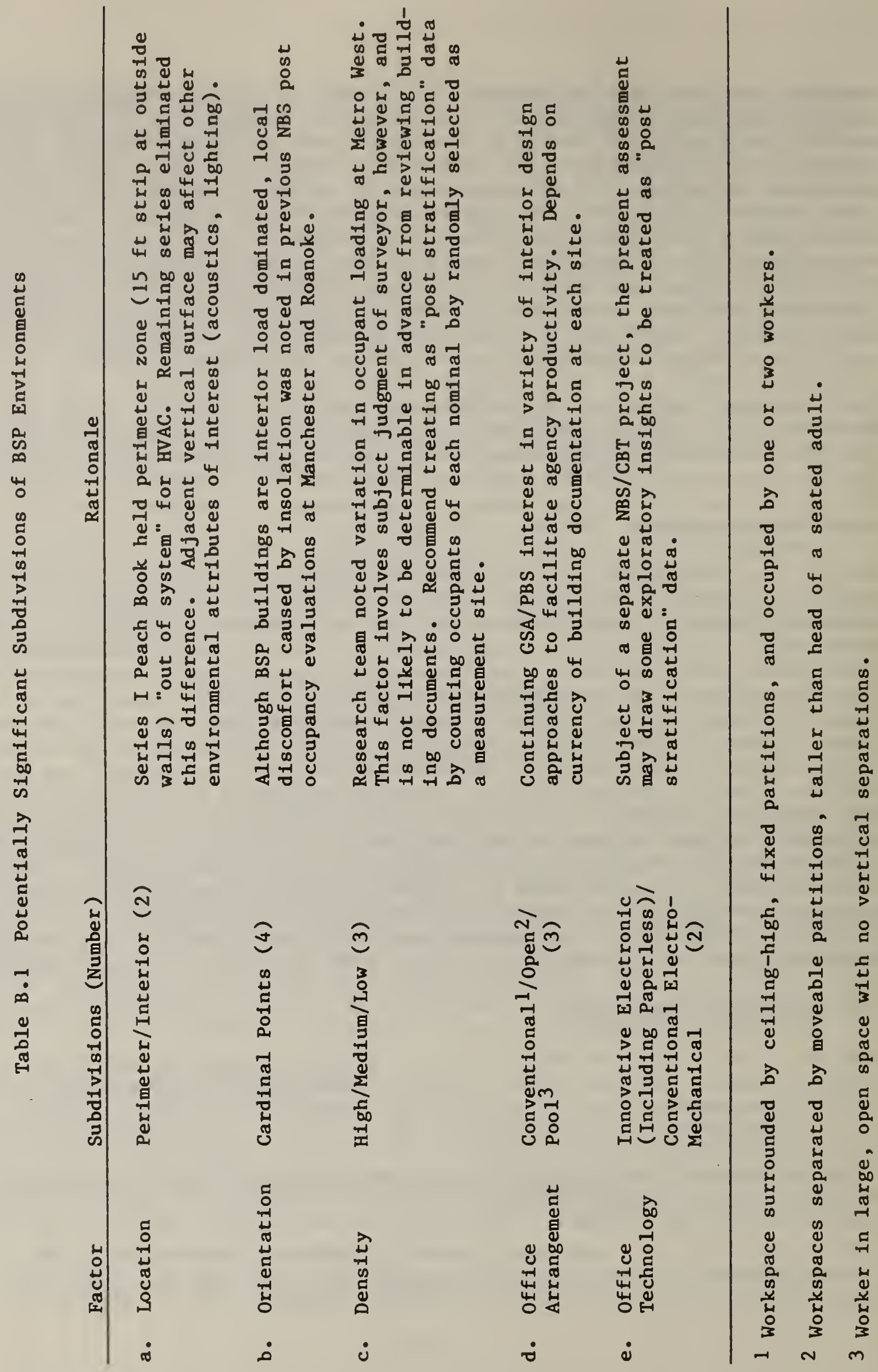


those in figure A.4, the surveyor will assign a unique number to every nominal bay and, by drawing from a table of random numbers, select the locations for measurement. Then, and only then, will the surveyor accompanied by the bullding manager (or representative) make an orientation tour of the entire structure.

\section{B. 5 PHYSICAL MEASUREMENTS}

This section specifies field methods and protocols for measuring the in-service performance of selected attributes of the BSP building. The attributes are acoustics, illumination, conditioned air, and "planning", the Peach Book's designation for flexibility of the interior space dimension system. Table 5.2 provides the rationale GSA/PBS and NBS/CBT used in making this selection and the methods used. The present section may be considered an expansion of table 5.2 in the direction of identifying where field measurement could be improved to facilitate future building evaluations.

\section{B.5.1 Illumination}

Peach Book:2, the basis of the Metro West and applicable to over half of the BSP space, stipulated six illumination requirements, each with its own test method. Requirement 4, Uniformity, is the only one of the six requirements, however, amenable to a practicable field measurement method providing a direct or approximate comparison of the in-service performance of the luminaire subsystem with the Peach Book's comprehensive lllumination requirements. The remaining five illumination requirements each stipulate a calculation procedure as the test method and these analytic methods cannot, by their very nature, be subjected to field measurement.

But future lighting criteria will likely include combined measures of illuminance level and contrast renditionl. While no fully-agreed procedure or target task exists, measurement instruments are available in the U.S. and Sweden for making combined measurements ${ }^{2}$. These instruments are not intended for exact photometry, but they are reported to produce results with accuracy and precision suitable for engineering practice and will be used in the BSP assessment. The SH and G Contrast/ESI meter cited table 5.2 is the instrument chosen.

The Equivalent Sphere Illumination (ESI) method upon which was based the GSA/PBS Peach Book illumination subsystem performance specification is not

1 Gary T. Yonemura, "Criteria for Recommending Lighting Levels," Lighting Research and Technology, 13:3, 1981, pp. 113-129.

2 I. Goodbar, "The Application of the ESI System to office Lighting", Lighting Design and Application (November 1982), p. 29 ff. 
without 1 ts criticsl. The criticisms address both the conceptual basis of ESI and the practical difficulties of executing large numbers of calculations determining ESI ratings of proposed lighting systems. Use of the ESI methods In the present assessment nelther expresses nor Implies their endorsement by NBS. Rather, the methods are used because they were specifically cited in Peach Book's second and third edftions and because no single substitute fleld evaluation method has, as yet, been widely accepted by the lighting community.

\section{B.5.2 Acoust1cs}

Peach Book: 2 sought to achieve an appropriate acoustical environment by stimulating the development of seven bullding system components (figure 2.2) which, although primarily intended for other purposes such as 1llumination or thermal comfort, would nevertheless, be evaluated for acoustical performance, as well, by being assessed for inclusion in the BSP. GSA/PBS evaluation methods required verification of system component performance as tested elther in the laboratory with each component being labelled or component fleld measurements with certification of performance. The specifled fleld measurements focus upon verification of specific performance attributes and require extensive set-up conditions and data reduction. Further, these tests must be conducted in the absence of normal office-generated nolse $e^{2}$ As a result, field measurements are not sultable for conducting bullding-wide nolse sampling to document the workplace environment as required in the current project since they are predicated upon conditions other than those prevalling during normal bullding occupancy.

The recommended acoustlcs measurement protocol involves a two-step process to be performed at each work station selected for sampling. The first step Involves completion of a check 11st documenting the physical conditions prevalling at each work station. The second step involves measurement of the sound level at each work station. The objective of this protocol will yleld qualitative data regarding system performance and qualitative data on the prevalling work station sound level. Because of 1ts simpliclty, these data are attalnable on a bullding-wide basis during normal working hours. Further, the protocol should not interfere with the worker's normal routine.

\section{B.5.3 Cond1tioned Alr (Movement)}

All editions of the Peach Book speclfled upper and lower limits alr movement occupled zones of 0.25 and $0.10 \mathrm{~m} / \mathrm{s}$ ( 50 and $20 \mathrm{ft} / \mathrm{min}$ ). The specification

1 The Illuminating Engineering Soclety's views on the uses of ESI are set forth in the IES L1ghting Handbook, Reference Volume (New York: IESNA, 1981), pp. 9-60 - 9-71. For a more skeptical view, see J. A. Lynes, "Lighting Design at the Crossroads," Bullding Services (U.K.), Apr11 1982, p. 53.

2 These tests are documented 1n, Test Methods for Direct-Measurement of Speech Privacy Potential Based on Subjective Judgements (PBS.C1) and Test Methods for the Sufficient Verfflcation of Speech Privacy Potential Based on Objective Measurements Including Methods for the Rating of Functlonal Interzone Attenuation and NC Backgrounds (PBS C.2), Washington, DC, GSA/PBS, May 1975. 
is amblguous, however, about whether throw-terminal or area-factor velocity measurements are required. Furthermore, the Alr Diffusion Counc1l Equipment Test Code, the standard referenced in Peach Book:2, 1s similarly unclear. The amblguity was resolved only after two GSA staff members involved in the initial drafting of the Peach Book were consulted and determined that throw-velocity is the required quantity.

As is pointed out in table 5.2, state-of-the art hot-wire anemometry cannot reliably measure velocities as low as the Peach Book's lower limits, making a definitive determination of the completed BSP bullding's compliance problematical. Metro West measurements were nowhere near the specifled upper limit, elther. This inability to reliably measure may be a reason that ASHRAE Standard 551981, Thermal Environmental Conditions for Human Occupancy, prescribes no minimum velocity; ASHRAE cites the same upper limit as does the Peach Book ( $50 \mathrm{ft} / \mathrm{min}$ or $0.10 \mathrm{~m} / \mathrm{s}$ ). Unless a rationale for maintaining the lower $11 \mathrm{mit}$ is available, GSA/PBS might consider eliminating the lower limit, bringing the Peach Book into conformance with the prevaliling standard in the building industry, ASHRAE 55. This elimination might be difficult, however, for air movement has been an object of contention in previous BSP evaluations.

\section{B.5.4 Planning (Flexibility of Interior Space Division)}

The Peach Book sought to extend the federal office building's service life by specifying high-performance interior space division systems. These systems afforded GSA building managers the ability to reconfigure interfor space to better serve the inevitably changing purposes of the tenant agencies. Building flexibility is an amorphous term: it can mean relocatability of functions, or their expandibility. During the BSP, flexibility was understood to mean the rearrangement or re-subdivision of the large and undifferentiated volume of the typical office floors erected in the program. The need for subdivision is obvious when one considers that, except for Peach Book:1, GSA/PBS Imposed no upper limit on the size of office floors. (Peach Book:3 did away with lower limits as well, allowing designers much greater freedom.)

Although flexible, reconfigurable subdivisions of larger architectural volumes have been an element of design thought since at least 1849 , it became significant after 1890 when steel and reinforced concrete frame construction became rellable and economicall, there is scant rellable empirical evidence of the extent to which such built-in flexibility is actually exported after inftial occupancy, and at what cost. 2

1 Peter Collins, Changing Ideals In Modern Architecture: 1750-1950 (Montreal, McG111 University Press, 1967), p. 234.

2 One published economic study was found in the author's personal collection: John C. Hamilton, "Functional Life as a Basis for Design" Industrialization Forum, Vol. 6, no. 3-4 (1975), pp. 71-82. A Computer search of The Engineering Index from 1970 to November 1982 revealed no others. 
Table B.5.4.1 Rate of Change and Area of Change Factors for Planned Change of BSP Interiors*

\begin{tabular}{|c|c|c|c|}
\hline \multirow[t]{2}{*}{ SUBSYSTEM } & \multicolumn{2}{|c|}{$\begin{array}{l}\text { ANNUAL RATE } \\
\text { OF CHANGE }\end{array}$} & \multirow{2}{*}{$\begin{array}{l}\text { AREA PER } \\
\underline{1000} \text { SQ. FT. } \\
\text { PB : } 3\end{array}$} \\
\hline & $\mathrm{PB}: 2$ & PB : 3 & \\
\hline Structure (sprinkler) & 0.035 & 0.035 & $25 \%$ \\
\hline HVAC & 0.035 & 0.035 & $25 \%$ \\
\hline \multicolumn{4}{|l|}{ Electrical D1stribution } \\
\hline Office Power & 0.11 & 1.2 & $85 \%$ \\
\hline Telephone & 0.18 & 1.32 & $85 \%$ \\
\hline Signal & 0.15 & 0.375 & $85 \%$ \\
\hline Lumina1re Sw1tching & 0.035 & 0.035 & $25 \%$ \\
\hline Luminalres & 0.03 & 0.03 & $100 \%$ \\
\hline Finished Floor & 0.10 & 0.10 & $85 \%$ \\
\hline Finished Celling & 0.10 & included & with other subsystems \\
\hline \multicolumn{4}{|l|}{ Space Dividers } \\
\hline Partitions & 0.07 & 0.07 & $25 \%$ \\
\hline Screens & 0.02 & 0.15 & $75 \%$ \\
\hline
\end{tabular}

* Peach Book:1 specified planned change in a manner incommensurate with the specifications in the later two editions.

$$
\text { B-8 }
$$


The current assessment will compare the areas and rates of change actually experienced in the $8 i x$ BSP buildings with the areas and rates listed in Peach Book:2, Appendix B (Planning Change); table 1, Amendment 8 (September 1975), p. 12 and Peach Book:3, Appendix G (Planning Charge), table 1, Amendment 1 (April 1976). The "rate of change" in both cases (none were specified in Peach Book:1) are defined as the "estimated annual rate of planning change by subsystem within the Typical Office Space". The "Area of Change" is an "estimate of the percentage of Typical office Space in which a subsystem will be installed or subject to change." Areas and rates are listed in table C.5.4.1.

Scientists and scholars have long used archival records, often originated for administrative purposes, as a source of research data. ${ }^{3}$ This practice has many advantages: the data is "clean", in that the producer does not know it will be used for research, and it is relatively inexpensive. But there are difficulties, too, namely: "selective deposit and selective survival" 4 - not every event is recorded correctly and not all records are retained. Hamilton, who used administrative records at two Army Installations to measure the frequency and extend of building conversions and alterations, noted that since Department of Defense level authorlzation is needed for conversions, "many such jobs are labelled diversions (where it is planned that the building will resort to 1 ts original use) and go unreported" 1 . This is an example of selective deposit in the archival record and an instance of what might be encountered in examining the Refmburseable Work Authorizations in the GSA/PBS field offices. In fact, one resident GSA building manager remarked that, in times of budget stringency in which funds for facility improvements are either deferred or foregone completely, tenant agencies might request space modifications within broader accounting categories not similarly curtalled, making it difficult for analysts to trace which specific bullding subsystems were altered at any given time.

Such risks of error or bias must, at least, be recognized at the outset and, to the extent possible, controlled for by the use of additional multiple measurements in the buildings and by speaking directly with the building managers.

1 Many such practices are described in Eugene J. Webb, et. al., Unobtrusive Measures: Non-reactive Research in the Social Sclences (Chicago: Rand McNally, 1966). Particularly Chapters 3 and 4.

2 Webb, et. al., p. 54 .

3 Hamilton, p. 77 . 


\section{B.6 PERCEPTUAL/BEHAVIORAL MEASUREMENTS ${ }^{1}$}

One of the driving forces energizing the BSP was a commitment to spur technological 1nnovation in meeting the user needs of the federal office workforce. The early editions of the Peach Book argued that since over 90 percent of the costs of dolng business in office bulldings over 1 ts 40 year economic I1fe was assignable to the wages and salaries of these employer therein, then the merest enhancement of their productivity that might result from a more satisfactory useroriented environment would dwarf the 2 percent of total costs (over the 40 year life) assigned to designing and bullding the structure. 2 clearly, then, the user mattered. What means are avallable for measuring the extent to which the BSP successfully addressed these user needs. Obviously, more than one method 18 needed but the s1x BSP buldings as they are percelved both by the federal office worker for whom they were intended and by the manager who operates the bulldings for the occupant's benefit.

NBS staff w1ll carry out these latter assessements by surveying the occupants of the structural bays 1dentified in the spatially-distributed random sample described in C.4. These occupants w1ll be asked to take 15 to 20 minutes to complete a questionnalre about the physical environment of their work stations. No one w1ll see the completed questionnaire except members of the research team, and the results will be tabulated in a statistical form for the bullding as a whole. While individuals completing the questionnaire will be identified by name, the research team must know approximately where in the building the responding occupant works so that the environmental conditions (11ghting, noise levels, etc.) can be measured objectively and compared with the occupant's subjective descriptions. Therefore, each questionnalre will carry an 1dentification number corresponding to a location in the bullding.

The questionnalre will record user perceptions and action as they relate to the four Peach Book performance attributes identifled earlier as being particularly salient in the occupant's lmmediate work environment. This is reiterated because the current project arises not to "evaluate a bullding" but, rather to assess the effectlve dellvery of selected bullding attributes after several years of service.

1 GSA/PBS has determined that the work described in this section should be rescheduled, in conformance with revised program object1ves within GSA as a whole, to later in the GSA/NBS research program. Consequently, the discussion concentrates on the concepted approach to measuring occupant perceptions and actions.

2 Th1s argument appears early in section B of Peach Book:1, 1R; and 2. It does not appear in the less hortatory Peach Book:3.

$$
\text { B-10 }
$$


Many elements in the questionnaire will replicate those used in earlier NBS and GSA collaborations on bullding evaluations 1 and on the Steelcase-sponsored national study of office workers conducted by the Louis Harris organization. This will be done so that the response of workers sheltered in BSP bulldings can be compared with response in those other office environments. Of course, for some highly important issues -- as determined jointly by GSA and NBS -more than a single question will be asked. This is done to assure internal consistency within a single occupant's response.

Once the physical environmental and occupant response data are in hand, the analysis will focus on comparisons between responses of users from buildings built under the three sets of Peach Book performance criteria. Additionally, comparisons of responses from buildings within the same series will be made. NBS analysts will also examine relationships between actual physical conditions as measured in the field and people's responses to these conditions. Univariate distributions will be prepared for all variables and, where appropriate, summary statistics including means and standard deviations will be calculated. Whenever possible, indices representing composite measures of people responses to a particular environmental attribute (e.g., illumination, noise) will be used. NBS w111 also perform a number of bivariate and mulitvariate analyses as an exploration into unsuspected regularities in a building's physical performance and the user perceptions and actions that performance induces. All this information can be useful to GSA/PBS in the planning, design, management, and operations of existing and proposed federal bulldings.

1 Notable examples include Robert W. Marans and Kent F. Sprekelmeyer, Evaluating Built Environments: A Behavioral Approach, (Ann Arbor, MI: University of Michigan Institute for Social Research, 1981). This book reported an evaluation of the Ann Arbor Federal Building first occupied in 1977. See also Elder and Tibbott and Elder, Turner and Rubin cited earlier. 
NBS. 114A (REV. 2.80$)$

\begin{tabular}{|c|c|c|c|}
\hline $\begin{array}{c}\text { U.3. DEPT. OF COMM. } \\
\text { BIBLIOGRAPHIC DATA } \\
\text { SHEET (See Instructions) }\end{array}$ & $\begin{array}{c}\text { 1. PUBLICATION OR } \\
\text { REPORT NO. } \\
\text { NBSIR } 83-2662\end{array}$ & . Performing Organ. Report Nof 3. Publication Date & February 1983 \\
\hline
\end{tabular}

4. TITLE AND SUBTITLE

Documentation and Assessment of the GSA/PBS Building Systems Program:

Background and Research Plan

5. AUTHOR(S)

Francis T. Ventre

6. PERFORMING ORGANIZATION (If joint or other than NBS, see instructions)

7. Contracu Grant No.

MATIONAL BUREAU OF STANDARDS

DEPARTMENT OF COMMERCE

WASHINGTON, D.C. 20234

9. SPONSORING ORGANIZATION NAME AND COMPLETE ADDRESS (Street, CIty, Stote, ZIP)

Public Bulldings Service

General Services Administration

Washington, DC 20405

10. SUPPLEMENTARY NOTES

DDocument describes a computer program; SF-185. FIPS Software Summary, is attached.

11. ABSTRACT (A 200-word or less foctuol summory of most significant information. If document includes a signlfleont bibliography or literoture survey, mention it here)

This report documents the orfins and conduct of the General Services Administration/Public Buildings Service (GSA/PBS) Bullding Systems Program (BSP) undertaken during the 1970 s and recommends a research plan for assessing the effectiveness of the BSP. The report proposes specific methods for assessing two outcomes of the BSP: the delivery of specified levels of performance for four attributes in the six bulldings completed under the BSP and the wider effects of the BSP on the building community.

12. KEY WORDS (Six to twelve entries; olphabetical order; copitallze only proper names; and seporate key words by semicolons) Building measurement; building systems; Federal bulldings; fleld assessment; office buildings; performance specification; post-occupancy evaluation; procurement; technical innovation

13. AVAILABILITY

[ Unlimited

$\square$ For Official Distribution. Do Not Release to NTIS

$\square$ Order From Superintendent of Documents, U.S. Government Printing Office, Washington, D.C. 20402.

14. NO. OF PRINTED PAGES

67

[X] Order From National Technical Information Service (NTIS), Springfield, VA, 2216I

15. Price

$\$ 10.00$ 

